I N T ER N ATIONAL MONETARY FUND

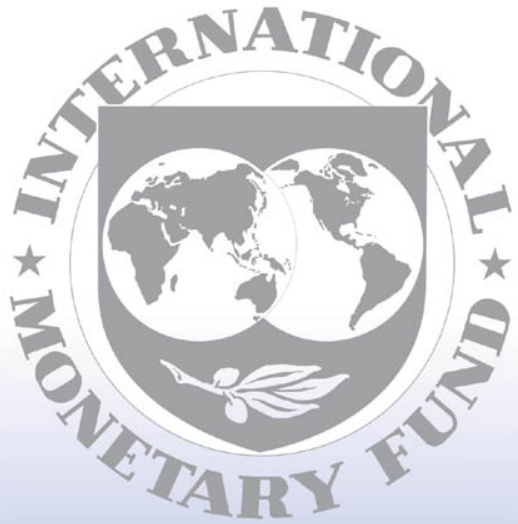

Staff

Country

Reports 


\section{Canada: Financial Sector Assessment Program-Detailed Assessment of Observance of the CPSS/IOSCO Recommendations for Securities Settlement Systems}

This Detailed Assessment of Observance of CPSS/IOSCO Recommendations for Securities Settlement Systems for Canada was prepared by a staff team of the International Monetary Fund as background documentation to the Financial Sector Assessment Program with the member country. It is based on the information available at the time it was completed in January 2008. The views expressed in this document are those of the staff team and do not necessarily reflect the views of the government of Canada or the Executive Board of the IMF.

The policy of publication of staff reports and other documents by the IMF allows for the deletion of market-sensitive information.

To assist the IMF in evaluating the publication policy, reader comments are invited and may be sent by e-mail to publicationpolicy@imf.org.

Copies of this report are available to the public from

International Monetary Fund $\bullet$ Publication Services

700 19th Street, N.W. • Washington, D.C. 20431

Telephone: (202) 6237430 • Telefax: (202) 6237201

E-mail: publications@imf.org • Internet: http://www.imf.org

Price: $\$ 18.00$ a copy

International Monetary Fund

Washington, D.C. 
This page intentionally left blank 


\title{
FinANCIAL SeCtor AsSessment PROGRAm
}

\author{
Detailed ASSESSMent OF OBSERVANCE OF THE CPSS/IOSCO \\ RECOMMENDATIONS FOR SECURITIES SETTLEMENT SYSTEMS
}

\section{CANADA}

JANUARY, 2008 
Contents

Glossary

Tables

1. Detailed Assessment of Canada's Observance of the CPSS-IOSCO Recommendations for Securities Settlement Systems ........................................................................................... 2. Summary Observance of CDSX of the CPSS-IOSCO Recommendations for Securities

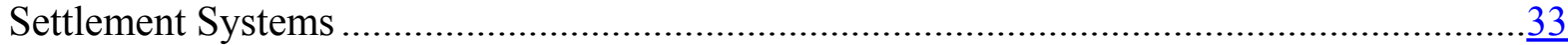

3. Recommended Action Plan to Improve Observance of CDSX of the CPSS IOSCO Recommendations for Securities Settlement Systems 


\section{GLOSSARY}

ACCESS

ACV

AMF

ASAP

$\mathrm{BCP}$

BOC

BNS

CAD

CBM

$\mathrm{CCP}$

CDS

CDSX

CNS

CPA

CPSIPS

CPSS

CSA

CSD

CVTS

DBNA

DTC

DTCC

DVP

IDA

IDD

IOSCO

LVTS

MTM

NSCC

NYL

OBS

ONB

OSC

OSFI

OSTA

PCSA

PPSA

RAC

SRO

STA

SWIFT

TFT

TSX

UCC
American and Canadian Connection for Efficient Securities Settlement

Aggregate Collateral Value

Autorité des marchés financiers

Account Services and Payments

Bank of Canada

Batch Net Settlement

Canadian dollar

CDS/DTC Cross-Border Movement

Central Counterparty

Clearing and Depository Services Inc.

Canadian Depository for Securities' Settlement System

Continuous Net Settlement

Canadian Payment Association

Core Principles for Systemically Important Payment Systems

Committee on Payments and Settlements Systems

Canadian Securities Administrators

Central Securities Depository

Collateral Value and Transfer System

Depository Bills and Notes Act

Depository Trust Company

Depository Trust and Clearing Corporation

Delivery-versus-Payment

Investment Dealers Association

Infrastructure Development Division

International Organization of Securities Commissions

Large Value Transfer System

Mark-to-Market

National Securities Clearing Corporation

New York Link

Overnight Batch Settlement

Ontario Securities Commission

Office of the Superintendent of Financial Institutions

Ontario Securities Transfer Act

Payment Clearing and Settlement Act

Personal Property Security Act

Risk Advisory Committee

Self Regulation Organization

Securities Transfer Act

Society for Worldwide Interbank Financial Telecommunication

Trade-for-Trade

Toronto Stock Exchange Inc.

Uniform Commercial Code 


\section{Table 1. Detailed Assessment of Canada's Observance of the CPSS-IOSCO Recommendations for Securities Settlement Systems}

\begin{tabular}{|l|l|}
\hline Recommendation 1. & $\begin{array}{l}\text { Securities settlement systems should have a well-founded, clear and transparent legal } \\
\text { basis in the relevant jurisdiction. }\end{array}$ \\
\hline Description & $\begin{array}{l}\text { Accessibility of the regulatory framework } \\
\text { The Canadian Depository for Securities (CDS) is the operator of the securities } \\
\text { settlement system (CDSX). All key laws, regulations, contractual arrangements, rules } \\
\text { and procedures governing the operations and activities of the CDSX are public and } \\
\text { accessible to participants. In particular, participants receive comprehensive } \\
\text { documentation covering the rules, requirements, procedures, and instructions } \\
\text { pertaining to CDSX. This documentation is available on request and is accessible on } \\
\text { the CDS website. The public authorities' regulations are also available to the general } \\
\text { public on their websites. }\end{array}$ \\
\hline
\end{tabular}

\section{Legal basis}

Securities clearing and settlement activities in Canada are governed and regulated by specific laws and regulations and by provisions in other financial legislation and regulations:

- The federal Payment Clearing and Settlement Act (PCSA), enacted in 1996 and amended in 2007, empowers the Bank of Canada (BOC) to designate and oversee clearing and settlement systems that could pose a systemic risk to Canadian financial markets. The BOC is authorized and responsible for regulating CDSX in a manner that will limit systemic risk. The PCSA protects settlement rules and procedures in CDSX from certain legal challenges and thus provides a high degree of legal assurance to the settlement process in CDSX.

- The Ontario Securities Act and the Québec Securities Act recognize, authorize, and regulate clearing houses to provide a clearing service.

- Other relevant legislation related to the issuance, immobilization, book-entry, and transfer of federal government, provincial government, and corporate securities include the federal Bills of Exchange Act, the federal Depository Notes and Bills Act, the Ontario Business Corporations Act, and equivalent statutory instruments in other provinces.

- The Canadian Securities Administrators National Instrument 54-101grants to nonregistered and registered securities holders equivalent access to corporate information and voting rights.

- Clearing and Depository Services Inc. (CDS) also qualifies as an eligible foreign custodian with the Securities and Exchange Commission of the United States and is, thus, subject to the Investment Companies Act (1940).

\section{Legal Basis for Book-Entry Transfers and Pledges}

Transfers of property rights (including ownership interests and security interests) in securities are governed generally by provincial law. Ontario (the jurisdiction where CDS's operations are centered), Alberta, and British Columbia (two other major headoffice jurisdictions) have recently enacted the uniform Securities Transfer Act (STA), which, in combination with amendments to those provinces' Personal Property Security Acts (PPSA), provide a modernized legal basis for book-entry transfers and pledges in CDSX. Closely modeled on Article 8 of the United States Uniform Commercial Code, the STA provides that a credit entry to a securities account at a securities clearing house creates a bundle of rights in favor of the credited account holder - known as a "security entitlement." If the account holder takes the security entitlement as a means of purchasing the securities, it renders the entitlement free and clear of any adverse claims to the security, as long as the account holder gave value for the securities and did not have any notice of an adverse claim. If the account holder 
takes the security entitlement as a means of perfecting its security interest in the securities, the account holder obtains a priority security interest in those securities, and this has priority even over the competing claims of another creditor who has previously registered an interest against the same property under the registration provisions of the PPSA. Québec is the other major head-office jurisdiction, the laws of which could possibly be applied to transfers and pledges of securities in CDSX (see below under conflict of laws issues).

Transfers of certain specific types of securities in CDSX (bankers' acceptances and commercial paper) will also be governed by the federal Depository Bills and Notes Act (DBNA). The DBNA provides that entries to the securities accounts of participants in a securities clearing agency constitute transfer of possession of those securities for the purposes of transferring ownership and of perfecting security interests. The federal government is currently considering whether the DBNA should be amended or repealed in response to the provincial STAs.

\section{(a) Enforceability of transactions}

The contractual arrangements between CDS and its participants are fully enforceable under Canadian laws. CDSX regulations can be enforced by a legal action.

Furthermore, the PCSA provides protection against stays being imposed on CDS realizing on security granted by participants who have become insolvent.

\section{(b) Protection of customer assets}

Assets held in trust at a custodian are held in segregated accounts and are thus protected from seizure in the event of the insolvency of the custodian. This fiduciary relationship is governed by general commercial law. At the level of the CDS, an intermediary is obliged to keep its securities holdings separate from customers' holdings. CDS is also required to keep its own securities holdings separate from the assets of its participants.

In addition, entities acting as custodians such as banks, investment firms, and other financial intermediaries are legally obliged to have an internal accounting system that allows the identification of the holdings of their customers at any time.

\section{(c) Immobilization and dematerialization of securities}

The great majority of securities issued in Canada are either dematerialized or immobilized in CDSX. The book-entry transfers and pledges of securities are governed mainly by provincial legislation. The laws of Ontario, Québec, and British Columbia, as well as the federal laws of Canada, explicitly recognize bookentry title, transfers, and pledges of securities. For debt securities issued by the federal government, the Financial Administration Act provides for the possibility of fully dematerialized federal debt securities. For securities governed by the federal DBNA (commercial paper, bankers' acceptances), a single certificated security for each issue must be deposited into CDSX and immobilized.

CDS is located in Ontario and governed in this respect by Ontario securities law. The Ontario Securities Transfer Act (OSTA), which came into force on January 1, 2007, provides a legally sound basis for the electronic transfer of securities between member accounts in CDSX for the purpose of transfers of securities. Book-entry transfers of bills of exchange and promissory notes (including bankers' acceptances) are subject to the federal Depository Bills and Notes Act, which provides an explicit legal basis for the immobilization and book-entry transfers of those securities in CDSX.

The OSTA is closely modeled on Revised Article 8 of the Uniform Commercial Code (UCC) in the United States. The OSTA, together with corresponding amendments to the PPSA, replaces outmoded concepts of the transfer of possession of book-entry 
securities with the UCC concept that the holder of a book-entry position in securities acquires a "security entitlement." By controlling a security entitlement (through the securities being recorded in its account), the participant who takes a pledge of the securities in CDSX obtains a valid, first priority security interest in the securities.

\section{(d) Netting arrangements}

The PCSA ensures the validity of netting arrangements defined in accordance with the settlement rules of the system, notwithstanding any federal or provincial laws governing the insolvency of a CDSX participant. In addition, the OSTA provides that a clearing agency rule that governs rights and obligations between the clearing agency and its participants or among its participants is effective even if the rule conflicts with the OSTA or PPSA and affects another person who does not consent to the rules.

\section{(e) Securities lending arrangements}

Securities lending arrangements, including close-out netting and pledges of collateral, are explicitly protected in the event of insolvency of a counterparty by the "eligible financial contract" provisions in the federal insolvency statutes. The OSTA and PCSA ensure that the transfers and pledges of securities in CDSX to settle SLA transactions will be legally effective. See also Recommendation 5 .

\section{(f) Finality of settlement}

Securities and fund transfers are settled simultaneously, irrevocably, and finally in CDSX. Finality is defined by the rules of the CDSX as the discharge of a securities settlement obligation through the transfer of securities and funds irrevocably (after transfer) and unconditionally. The finality of settlement in the CDSX rules is, as noted, protected under the PCSA.

Net cash settlement (payment exchange in CDSX terminology) between settlement members in CDSX and CDS as the central counterparty is conducted through Large Value Transfer System (LVTS) payments on the books of the BOC. The LVTS is a payment system that adheres to the Core Principles on Systemically Important Payment Systems (CPSIPS). LVTS is also a designated payment system under the PCSA. Accordingly, the PCSA legally mandates that settlement of payment obligations on the books of the BOC is final and irrevocable upon entry, and not subject to reversal, set-aside, or stay.

Intraday settlement of individual securities transactions in CDSX, as well as the endof-day settlement of the net amounts owing, are protected from unwinds by the PCSA, which protects the enforceability of the finality provisions in the CDSX rules.

\section{(g) Delivery-versus-payment (DVP)}

Entries to securities accounts and corresponding entries to fund accounts are made simultaneously only after all risk control tests have been passed. The CDSX rules, as well as the design and functionality of the system, ensure that no transaction settles in CDSX unless securities are available and there is sufficient cash or credit to fully support the transfer of securities.

\section{Challenges by a court}

To date, there have been no court challenges to the settlement of securities transactions, end-of-day net cash settlement or to the protections provided to the rules of CDSX.

\section{Enforceability of rules and regulations in the event of a bankruptcy}

As indicated above, the PCSA explicitly validates and upholds the enforceability of CDSX rules as binding on CDSX and its participants, notwithstanding any federal or provincial insolvency laws. It also ensures that realization on collateral pledged in the 


\begin{tabular}{|c|c|}
\hline & 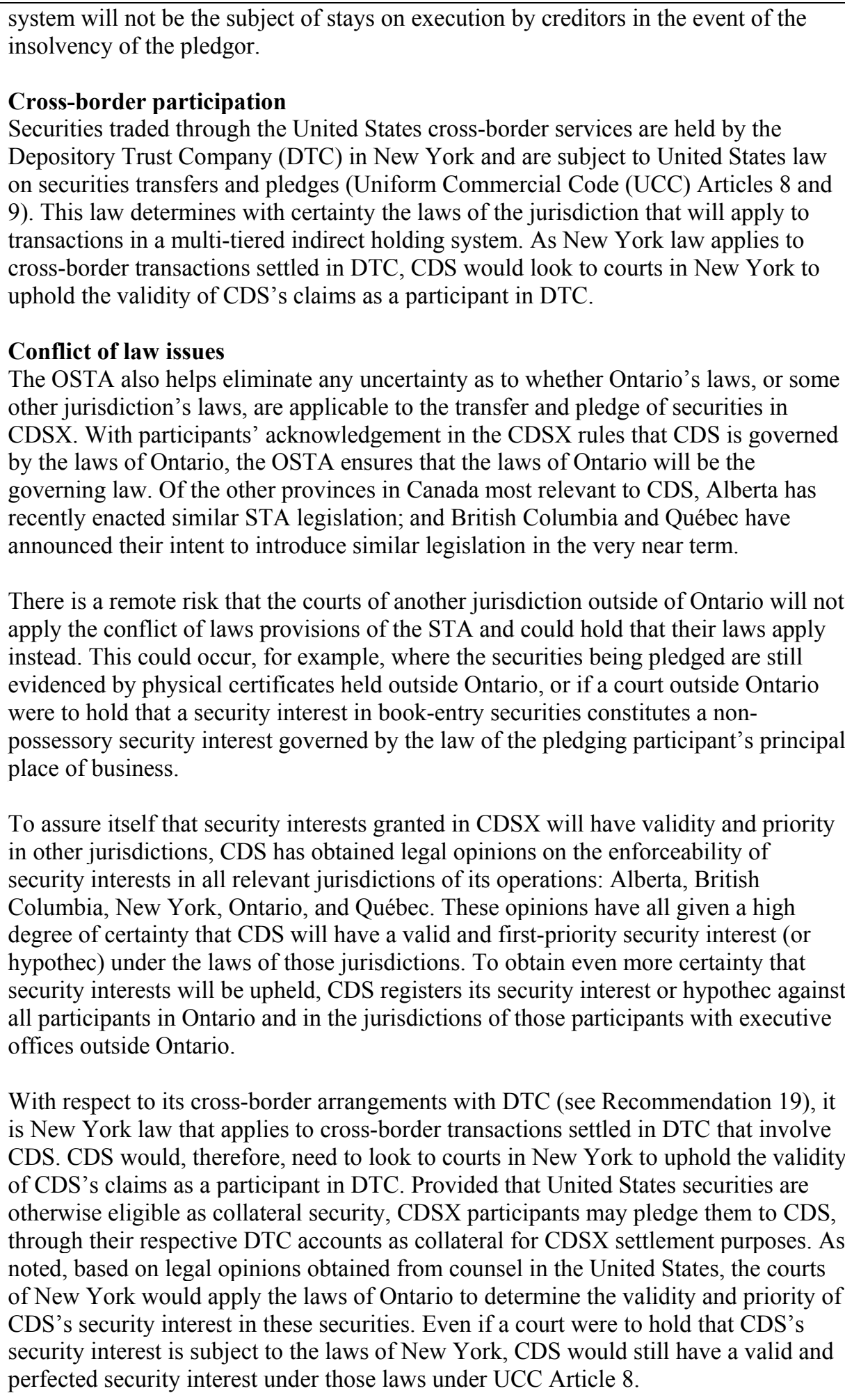 \\
\hline Assessment & Observed \\
\hline Comments & \\
\hline
\end{tabular}




\begin{tabular}{|c|c|}
\hline Recommendation 2. & $\begin{array}{l}\text { Confirmation of trades between market participants should occur as soon as possible } \\
\text { after trade execution, but no later than trade date }(\mathrm{T}+0) \text {. Where confirmation of trades } \\
\text { by indirect market participants (such as institutional investors) is required, it should } \\
\text { occur as soon as possible after trade execution, preferably on } \mathrm{T}+0 \text {, but no later than } \\
\mathrm{T}+1 \text {. }\end{array}$ \\
\hline Description & $\begin{array}{l}\text { Confirmation of trades entered into CDSX on T+O } \\
\text { CDSX has the capability for straight-through-processing (STP) of trade for trade } \\
\text { confirmation on T }+0 \text {. In practice, confirmation of trades, relative to trade date (T), } \\
\text { depends on whether a trade is between direct market participants ("non-institutional") } \\
\text { or between indirect market participants ("institutional"). } \\
\text { Direct/non-institutional } \\
\text { Transactions traded on the exchange are confirmed or "locked-in" automatically at the } \\
\text { exchange at T }+0 \text {. They are then moved to CDSX with a "confirmed" status and are } \\
\text { ready for settlement. Direct non-exchange trades between two participants of a } \\
\text { clearing agency are generally confirmed through the facilities of the clearing agency. } \\
\text { Dealer to dealer trades are subject to Investment Dealers Association (IDA) } \\
\text { Regulation } 800.49 \text {, which provides that trades in non-exchange traded CDS eligible } \\
\text { securities must be submitted to an "acceptable trade matching utility" within one hour } \\
\text { of the execution of the trade. In trade "matching," both parties to a trade targeted for } \\
\text { processing in CDS's trade matching service submit trade entry instructions, which are } \\
\text { compared and matched, resulting in the creation of a confirmed trade. The CDS can } \\
\text { also accept matched trades from a virtual matching utility, setting them up for } \\
\text { settlement as confirmed trades. } \\
\text { Indirect/institutional } \\
\text { Effective April } 1,2007 \text {, a new framework for trade confirmation for indirect } \\
\text { participants was adopted by the various jurisdictions of the Canadian Securities } \\
\text { Administrators (CSA). By July } 1,2008 \text {, market participants must confirm } 90 \text { percent } \\
\text { of their trades by T+1 or, if not, are required to submit an "exception report" to } \\
\text { regulators. The current situation is that about } 70 \text { percent of trades by volume are } \\
\text { confirmed by T+1. }\end{array}$ \\
\hline Assessment & Observed \\
\hline Comments & \\
\hline Recommendation 3. & $\begin{array}{l}\text { Rolling settlement should be adopted in all securities markets. Final settlement should } \\
\text { occur no later than } T+3 \text {. The benefits and costs of a settlement cycle shorter than } \mathrm{T}+3 \\
\text { should be assessed. }\end{array}$ \\
\hline Description & $\begin{array}{l}\text { Settlement cycles } \\
\text { Securities transactions are settled on a continuous basis using a rolling settlement } \\
\text { cycle. The regular schedule for rolling settlement is as follows: } \\
\text { - Equities }(\mathrm{T}+3) \text {. } \\
\text { - Government of Canada treasury bills and money market securities }(\mathrm{T}+0) \text {. } \\
\text { having remaining maturity of three years or less }(\mathrm{T}+2) \text {. } \\
\text { - Government of Canada bonds and Government of Canada guaranteed bonds } \\
\text { with remaining maturity of over three years, all provincial, municipal, } \\
\text { corporate and other bonds or debentures, equities, or other certificates of } \\
\text { indebtedness including mortgage-backed securities }(\mathrm{T}+3) \text {. } \\
\text { (OTC) trade settlement is negotiable between the counterparties, but the majority of } \\
\text { these transactions is settled similarly to exchange-traded securities. } \\
\text { Failed trades } \\
\text { Failed equities trades accounted for about } 0.5 \text { percent of the total number of trades }\end{array}$ \\
\hline
\end{tabular}




\begin{tabular}{|c|c|}
\hline & 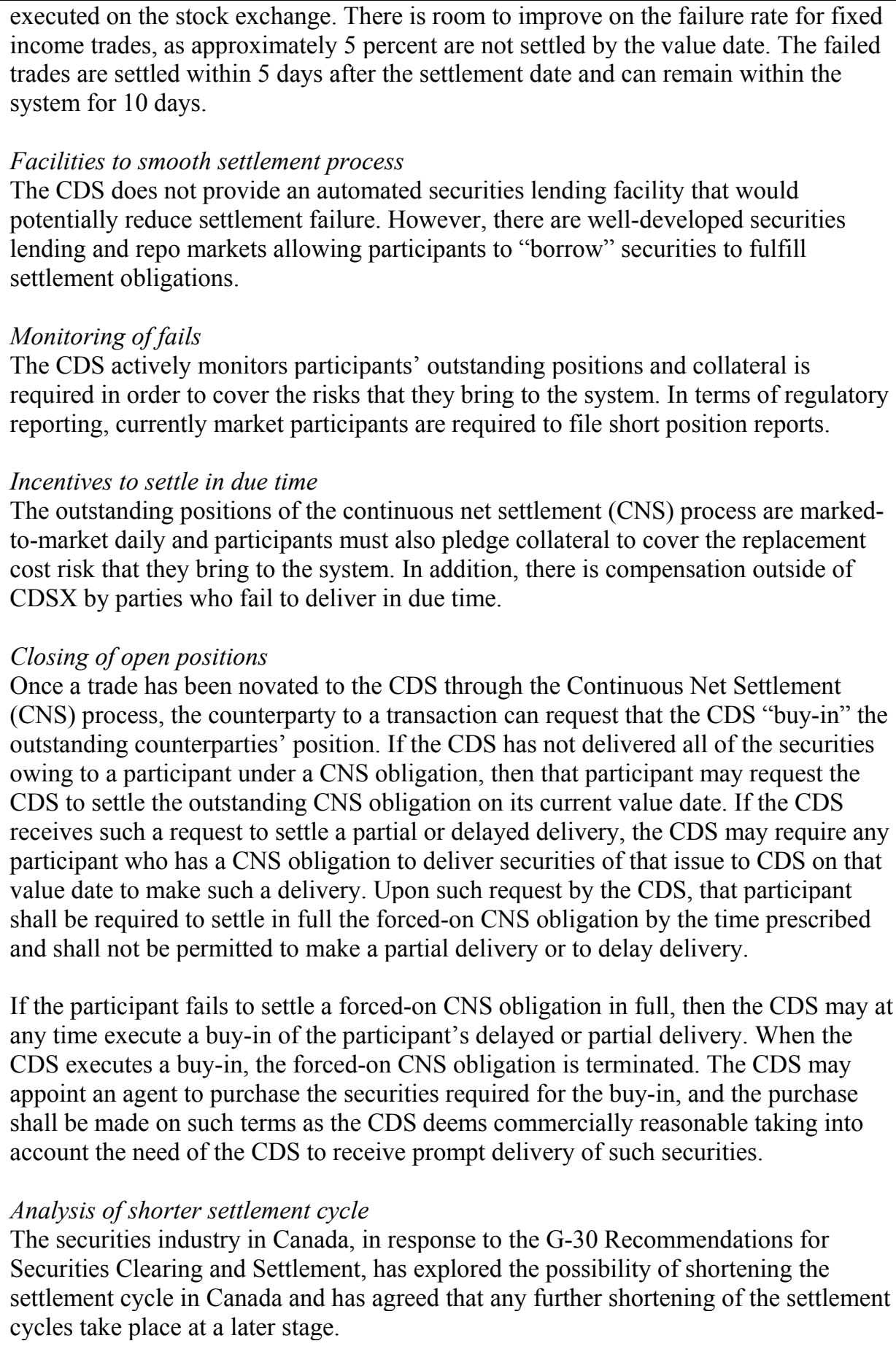 \\
\hline Assessment & Observed \\
\hline Recommendation 4. & $\begin{array}{l}\text { The benefits and costs of a central counterparty should be assessed. Where such a } \\
\text { mechanism is introduced, the central counterparty should rigorously control the risks it } \\
\text { assumes. }\end{array}$ \\
\hline Description & $\begin{array}{l}\text { CDS as central counterparty (Central Counterparty } \\
\text { The CDS becomes the CCP for cash payments that arise from all securities } \\
\text { transactions settled in CDSX. The CDS also acts as a CCP for the securities leg of } \\
\text { transactions that involve future-dated Canada bonds and treasury bills, through the }\end{array}$ \\
\hline
\end{tabular}




\begin{tabular}{|c|c|}
\hline & $\begin{array}{l}\text { DetNet clearing function, and for equities through the CNS function. } \\
\text { The CDS generally acts as a CCP at the date of settlement, however, in the case of } \\
\text { DetNet, novation of the payment and securities obligations can take place before the } \\
\text { settlement date. This means that the participants are facing replacement cost risk from } \\
\text { the time of trade execution T }+0 \text { until novation occurs, which is generally on settlement } \\
\text { date, but in the case of DetNet this can be earlier. International best practice would } \\
\text { require the CCP to assume its responsibility immediately after the trade is executed. } \\
\text { Cost-benefit analysis } \\
\text { No explicit cost-benefit analysis has been done for introducing CCP for trade-for-trade } \\
\text { (TFT) transactions, However, the pros and cons of offering the TFT service with a } \\
\text { CCP or without a CCP were implicitly evaluated as part of the decision to offer the } \\
\text { TFT service in CDSX without a CCP. Nonetheless, the regulators intend to raise with } \\
\text { CDS, for its consideration, the issue of providing TFT on a CCP basis. } \\
\text { Risk management } \\
\text { This recommendation deals only with the cost-benefit analysis of introducing CCP, } \\
\text { while the risk management procedures of the CCP, including margin requirements, } \\
\text { financial resources, default procedures, should be assessed separately against the } \\
\text { Committee on Payments and Settlements Sysstems CPSS/IOSCO Recommendations } \\
\text { for CCP. } \\
\text { Nevertheless, the CDS's credit and liquidity risk exposures in connection with the } \\
\text { settlement are assessed in order to ensure the safety of the settlement system (see } \\
\text { Recommendation 9). }\end{array}$ \\
\hline Assessment & Broadly observed \\
\hline Comments & $\begin{array}{l}\text { In order to fully observe this recommendation, the CDS should explicitly assess the } \\
\text { benefits and costs of acting as a CCP for trade-for-trade (TFT) transactions. }\end{array}$ \\
\hline Recommendation 5. & $\begin{array}{l}\text { Securities lending and borrowing (or repurchase agreements and other economically } \\
\text { equivalent transactions) should be encouraged as a method for expediting the } \\
\text { settlement of securities transactions. Barriers that inhibit the practice of lending } \\
\text { securities for this purpose should be removed. }\end{array}$ \\
\hline Description & $\begin{array}{l}\text { Institutional framework } \\
\text { Canada has well-developed securities lending and repo markets that can contribute to } \\
\text { the settlement process. The vast majority of repo and securities lending transactions } \\
\text { involve securities issued by the Government of Canada, but can also include } \\
\text { provincial, municipal, and corporate bonds, as well as equities and money market } \\
\text { instruments. Typical borrowers of securities include investment dealers, banks, } \\
\text { insurance companies, hedge funds, and individuals. Typical lenders include pension } \\
\text { funds, investment funds, mutual funds, investment dealers, and third-party lenders } \\
\text { (such as trustees). Custodians also play a key role in the securities lending market, } \\
\text { mainly as agents. They provide custody account management services, securities } \\
\text { valuation, and transfer administration services, notably investment and lending } \\
\text { services on behalf of their clients. Since Canadian dollar securities are held in the } \\
\text { CDS, the actual transfer of loaned and repoed securities is in the form of a book-entry } \\
\text { in the CDSX. } \\
\text { The Canadian tax regime does not differentiate between repo transactions and } \\
\text { securities lending arrangements. } \\
\text { The standardized documentation governing lending and borrowing transactions was } \\
\text { developed by the IDA and includes Securities Loan Agreements and Repurchase }\end{array}$ \\
\hline
\end{tabular}

\section{CInternational Monetary Fund. Not for Redistribution}




\begin{tabular}{|c|c|}
\hline & $\begin{array}{l}\text { Agreements. The banking supervisor, the Office of the Superintendent of Financial } \\
\text { Institutions (OSFI), also publishes guidelines for federally regulated financial } \\
\text { institutions involved in securities lending. Standard agreements exist and are used for } \\
\text { cross-border securities lending arrangements. } \\
\text { Market infrastructure } \\
\text { There is no centralized automated securities lending facility in Canada. All such } \\
\text { transactions are carried out on a bilateral basis. In 2006, CDS investigated the business } \\
\text { case for the creation of a new facility characterized as an "Automatic Lending } \\
\text { Program", where lending would automatically occur to cover short positions in CNS } \\
\text { on settlement date. CDS also investigated the business case for a "Voluntary Lending } \\
\text { Program", through which CDS would provide a single information source on } \\
\text { securities available for lending and borrowing, and functionality to match and } \\
\text { complete loan transactions between lenders and borrowers. However, discussions with } \\
\text { participants suggested that failed trades were not a significant problem and that the } \\
\text { business cases did not exist for developing these facilities. } \\
\text { Supervision and regulation of securities lending arrangements } \\
\text { There is no specific regulatory regime for securities lending and repo markets. } \\
\text { Participants in these markets are supervised by various prudential regulatory bodies, } \\
\text { such as the IDA, a self-regulatory organization for investment dealers, and OSFI for } \\
\text { federally regulated financial institutions. The IDA and provincial securities regulatory } \\
\text { authorities have in place specific and general rules that regulate domestic secondary } \\
\text { market trading carried out by IDA member firms. In addition, the Bank of Canada, the } \\
\text { Department of Finance, and the IDA have developed a formal code of conduct that } \\
\text { provides further amplification and, in some cases, broader application of these rules in } \\
\text { relation to domestic debt markets (Policy No. 5). }\end{array}$ \\
\hline Assessment & Observed \\
\hline Comments & $\begin{array}{l}\text { As there is room to improve on the failure rate for debt instruments, CDS might re- } \\
\text { consider introducing a securities lending facility in order to reduce settlement failure. }\end{array}$ \\
\hline Recommendation 6. & $\begin{array}{l}\text { Securities should be immobilized or dematerialized and transferred by book entry in } \\
\text { Central Securities Depository (CSDs) to the greatest extent possible. }\end{array}$ \\
\hline Description & $\begin{array}{l}\text { The great majority of securities issued in Canada are either dematerialized or } \\
\text { immobilized in the CDS. However, securities held by most active participants are } \\
\text { immobilized (approximately } 95 \text { percent of government securities, equities, and } \\
\text { corporate bonds, and } 90 \text { percent of corporate money market instruments). Not all } \\
\text { securities issued in Canada are dematerialized. However, all securities deposited in the } \\
\text { CDS - both dematerialized and immobilized-are recorded, managed, and transferred } \\
\text { through an electronic book-entry system. } \\
\text { Transfer of title } \\
\text { CDS operates an indirect account holding system. Securities are kept in the name of } \\
\text { the custodians, who act as a nominee for customers. The transfer of ownership occurs } \\
\text { when the securities are transferred among participants in the books of the CDS, which } \\
\text { notifies by electronic message the intermediaries that the transfer has been registered } \\
\text { in the relevant accounts held by the CDS. As soon as the intermediaries receive this } \\
\text { notification, intermediaries shall make the necessary entries in their sub-accounts. } \\
\text { The CDS does not carry out the registrar function. The listing of beneficial ownership } \\
\text { of securities is done by private transfer agents acting on behalf of issuers. However, } \\
\text { the transfer of ownership within the CDSX takes place on its books and does not } \\
\text { depend on a transfer of beneficial ownership at the registrar. }\end{array}$ \\
\hline
\end{tabular}




\begin{tabular}{|c|c|}
\hline & $\begin{array}{l}\text { last. } \\
\text { Once all the negative positions are excluded, the inclusion process is } \\
\text { performed to include as many TFT trades and CNS positions as possible } \\
\text { without causing any negative positions in the securities, funds, and ACV. } \\
\text { When the exclusion and inclusion processes are complete, the outstanding } \\
\text { CNS positions are created and the ledgers are updated to reflect the settled } \\
\text { CNS and TFT trades. If necessary, the system excludes TFT transactions } \\
\text { until the provisional negative position is eliminated. } \\
\text { The system executes all of the non-excluded CNS trades as settled, } \\
\text { executes the non-excluded TFT trades as settled and updates the excluded } \\
\text { TFT trades as pending. } \\
\text { All of the pending TFT trades are re-considered for settlement in the real } \\
\text { time TFT settlement process. All of the CNS outstanding positions are re- } \\
\text { considered for settlement in the intra-day CNS settlement process. } \\
\text { 7. } \\
\text { Finally, for CNS transactions that do not settle in the OBS settlement process (“CNS } \\
\text { outstanding"), settlement is re-attempted on a full or partial basis during one of four } \\
\text { settlement windows over the processing day, referred to as the intra-day CNS } \\
\text { processes. } \\
\text { Delivery versus payment } \\
\text { In CDSX, DVP is achieved through the simultaneous transfer of funds and securities } \\
\text { at the time of settlement of transactions. The funds and securities transfers are final } \\
\text { between the participants and CDS. At the end of the day, the obligations among the } \\
\text { CDS and settlement banks, acting as cash clearers, are settled through the LVTS } \\
\text { payments for Canadian Dollar (CAD) and FedWire funds for U.S. dollar. } \\
\text { Legal framework } \\
\text { The PCSA supports the legal framework of DVP; it makes the systems' settlement } \\
\text { rules binding by removing potential legal challenges to the rules. Both securities } \\
\text { deliveries and funds payments are irrevocable and unconditional. The systems are set } \\
\text { up so that securities and funds transfers in the accounts of participants are final once } \\
\text { settlement has been completed. Furthermore, end-of-day payments are made through } \\
\text { the large value transfer system (LVTS), a system that provides irrevocable and } \\
\text { unconditional funds on an intraday basis. } \\
\text { DVP and cross-border links } \\
\text { See Recommendation } 19 \text { for description of the cross-border links. } \\
\text { the }\end{array}$ \\
\hline Assessment & Observed \\
\hline \multicolumn{2}{|l|}{ Comments } \\
\hline Recommendation 8. & $\begin{array}{l}\text { Final settlement on a DVP basis should occur no later than the end of the settlement } \\
\text { day. Intra-day or real-time finality should be provided where necessary to reduce risks. }\end{array}$ \\
\hline Description & $\begin{array}{l}\text { Intraday finality } \\
\text { CDS provides real time finality and intraday finality. In fact, the TFT settlement } \\
\text { process allows real time finality after the execution of DVP settlement. For } \\
\text { transactions that settle in the overnight CNS/BNS settlement process, finality is } \\
\text { achieved after the execution of each batch. The (ONB) processes the CNS trades and } \\
\text { the batch net settlement (BNS) component processes the TFT and DetNet trades. The } \\
\text { goal of the combined process is to allow CNS and TFT activities to net against each } \\
\text { other and to reduce a participant's requirements for securities positions, funds, credit } \\
\text { and collateral while still satisfying the appropriate risk controls. The CNS/BNS } \\
\text { process occurs once per day after the overnight period around 4:00 am. EST. }\end{array}$ \\
\hline
\end{tabular}




\begin{tabular}{|c|c|}
\hline & $\begin{array}{l}\text { Finally, for CNS transactions that do not settle in the ONB, settlement is re-attempted } \\
\text { on a net basis during one of four settlement windows over the processing day. These } \\
\text { are referred to as the intra-day CNS processes. } \\
\text { The settlement of a trade results in a final and irrevocable delivery of securities and } \\
\text { funds on the books of the two trading parties. They can then reuse securities and funds } \\
\text { that have been transferred to them intraday or in real time. } \\
\text { Need for intraday real time finality } \\
\text { As a settlement participant in the CDSX, the BOC settles its securities transactions } \\
\text { that are related to monetary policy transactions and collateralized credit operations. } \\
\text { Except for some client account securities transactions, the majority of the BOC } \\
\text { securities transactions are for same-day DVP settlement in the TFT service. Similarly, } \\
\text { all its collateral transfers involve real-time transfers on a "free delivery" basis or } \\
\text { through DetNet. } \\
\text { Links to foreign CSDs } \\
\text { The CDS has links to CSDs in other countries to facilitate cross-border trading by its } \\
\text { members. As a rule, the CDS credits participants' securities accounts and makes } \\
\text { securities available only after confirmation of settlement finality on the local market } \\
\text { by the depository. However, DTC (the CSD in the United States) allows provisional } \\
\text { transfers. The CDS participants can move these securities from their DTC (sponsored) } \\
\text { account to their CDSX account, using the CDS's cross-border movement service. This } \\
\text { issue is discussed further in Recommendation } 19 \text { on links. }\end{array}$ \\
\hline Assessment & Observed \\
\hline Comments & \\
\hline Recommendation 9. & $\begin{array}{l}\text { CSDs that extend intraday credit to participants, including CSDs that operate net } \\
\text { settlement systems, should institute risk controls that, at a minimum, ensure timely } \\
\text { settlement in the event that the participant with the largest payment obligation is } \\
\text { unable to settle. The most reliable set of controls is a combination of collateral } \\
\text { requirements and limits. }\end{array}$ \\
\hline Description & $\begin{array}{l}\text { Risk management procedures } \\
\text { The CDS facilitates securities settlement by providing intra-day funds accounts to } \\
\text { participants, with positive net funds positions representing an end-of-day claim on the } \\
\text { CDS and negative net amounts representing a claim by the CDS on the participant. } \\
\text { The balances of the banks, acting as cash clearer, are settled at the end-of-day payment } \\
\text { exchange process. The credit risk associated with these balances is managed through } \\
\text { limits and collateralization. The CDS also acts as a CCP for the net settlement } \\
\text { procedures. Thus, the CDS is exposed to credit and liquidity risks. In addition, implicit } \\
\text { risk exposure occurs within the net settlement process in the event a participant is } \\
\text { unable to meet its obligations on time or at a later stage. } \\
\text { In order to handle these risks, the CDS's enterprise risk management program provides } \\
\text { a structured approach to the identification and management of those events that can } \\
\text { negatively impact the CDS's activities. Each division assesses and measures risks } \\
\text { according to their probability of occurrence and potential impact. These risk } \\
\text { assessments are reviewed at the enterprise level by a dedicated risk committee. For } \\
\text { each risk committee meeting, the key risk report for the applicable reporting period } \\
\text { documents changes to the enterprise-wide risk profile and provides the information } \\
\text { detailed above. In addition to ongoing identification and management of risk through a } \\
\text { self-assessment process, the CDS also conducts a thorough annual risk review that } \\
\text { comprehensively identifies the key risks faced by divisions and the strategies for }\end{array}$ \\
\hline
\end{tabular}


managing these risks. The report's findings are reviewed and approved by CDS senior management before they are reported to the audit/risk committee of the board of directors.

A complete risk review is also performed for every new service and significant enhancement to existing services to help ensure that appropriate controls are in place before implementation. This review process is integrated into the system and business development life cycle methodologies at the CDS.

In regard to the risk containment of the CDS's clearing and settlement services, risk management:

- designs, tests and implements suitable risk controls that together make up the risk model and any enhancements to the risk model;

- monitors participant settlement activity to help ensure that the risks being brought to the system are adequately mitigated;

- applies suitable additional measures to participants determined to be contributing excessive risks to the system;

- presents for review and approval by the risk committee and the board of directors proposed tolerances and limits and any changes to the risk model;

- regularly reports on results and any actions taken in applying the risk controls (highlighting exceptions) to senior management, the Risk Advisory Committee and the Audit/Risk committee;

- in coordination with the operations division, maintains and applies appropriate procedures to resolve participant defaults; and

- liaises with other CDS divisions to help apply appropriate risk controls.

\section{Risk Advisory Committee (RAC) and Risk Monitoring}

The RAC acts as an advisory group to the CDS on issues regarding the CDSX risk model and reports to the audit committee of the CDS's board of directors. The RAC, which meets at least once per month, has representatives from each participant category, the BOC, the IDA, the Ontario Securities Commission (OSC), the Autoritédes Marchés financiers (AMF), and members of the CDS management. This monthly report, circulated to the RAC members and the risk board committee, provides a summary of the results of the CDS's assessment of the financial risk measurements and controls applied in the CDSX. To monitor payment risk, the report provides metrics on the CDSX collateral pools and resulting credit facilities. To assess replacement cost risk, the report provides metrics on the largest aggregate risk and single participant exposure in each of the $\mathrm{CCP}$ services. It also covers the risk created by the largest outstanding position of any single participant in all the CCP services of which they are a member, and back-tests results for CCP participant funds, DetNet losses, and CNS losses. Finally, to assess liquidity risk, the report covers the CDS liquidity risk exposure in both currencies.

The CDS staff also monitors the system and related risk metrics in real time, with standard escalation procedures. For example, upon determination that a CDS receiver or credit participant has satisfied one or more of the conditions for suspension, an internal crisis management team at CDS becomes involved in making a decision. There is also a Problem Management Group that includes both CDS management and other CDS stakeholders.

\section{CDSX risk management}

\section{Membership standards}

The minimum requirements for participation vary depending upon the type of participant. In general, the CDS requires every participant to be subject to regulation and, if applicable, to be a member of a self-regulatory organization (SRO). The CDS 
also requires that participants be able to demonstrate that they meet basic financial and operational requirements, related to a participant's financial ability to meet its obligations to the CDS, and to its operational capabilities, including staffing needs.

\section{Credit risk controls}

The credit risk associated with participants' net cash settlement obligations to the CDS, as the CCP, is managed by limits on the maximum payment obligations that a participant can create in the system and collateralization of those payment obligations. These risk controls are ultimately supported by a structure in which each participant belongs to at least one of the "category" credit rings.

A category credit ring is a grouping of the CDSX participants that share similar characteristics. For example, the six largest banks in Canada are classified as Extenders of Credit and provide credit to other participants that are classified as Receivers of Credit. Each class of member is eligible to participate in a specific credit ring.

\section{Limits on payment obligations ("Funds Edit")}

All participants' funds accounts have a limit on the size of negative funds balances (essentially a limit on the maximum negative balance that the participant can have in its funds account at any point in time). The size of this limit is based on two factors:

- Caps: A cap is an amount that is assigned to a participant pursuant to a formula in the rules and procedures. Some participants are assigned a cap of zero. Only participants who are members of a collateralized category credit ring receive a cap.

- Lines of Credit: In CDSX, credit granters can provide lines of credit to other participants. Participants may receive multiple lines of credit from multiple credit granters. The Extender that grants a line of credit is ultimately responsible for covering the payment obligations that arose from use of that line.

\section{Collateralization of payment obligation ("ACV Edit")}

The CDS also performs a risk check to ensure that a participant's negative funds balance is fully collateralized - the Aggregate Collateral Value (ACV). No payment obligation is permitted unless it satisfies the ACV. The ACV is the estimated ("haircut- adjusted") value of the collateral that could be realized if the participant failed to meet its payment obligation. ACV is composed of securities maintained by a participant in certain of its accounts, and of a pool of securities contributed by members of the participant's category credit ring(s). This pool of securities is known as a category credit ring's collateral pool.

\section{Collateral pools}

The collateral pool associated with each credit ring provides some ACV to the members of that ring. The collateral pools work on the premise that obligations of multiple participants are covered by the same collateral, so the system is guaranteed to survive the default of at least the largest net debtor. If two or more participants from the same collateral pool were to fail while in a net intraday debtor position, the remaining (surviving) members of that collateral pool would ultimately be required to cover the portion of the defaulters' obligations that arose from use of the pooled collateral. For one of the pools, the CAD Receiver's of Credit Pool, the CDS monitors the members of the pool through its memorandum of understanding with the IDA. Members of the CAD credit Pool, who are on "Early Warning Level One" are subject to a special collateral charge equal to their normal collateral requirement, or may elect a cap equal to $50 \%$ of their calculated cap. Members who are on Early Warning Level Two must collateralize their calculated cap on a dollar-for-dollar basis. If defaults of 
participants (in this pool) were somewhat anticipated by regulatory authorities, then this mechanism would mitigate the losses to surviving members that result from the default of one or more of these participants.

\section{Replacement cost risk}

As a CCP, the CDS faces replacement cost risk should one of the participants in the CCP service default, leaving the CDS's obligation to complete the transaction with the surviving counterparty. Under this scenario, the CDS would be required to replace the defaulter's position in the market, which may have appreciated or depreciated in value since the trade date. The CDS protects itself against replacement cost risk by using daily mark-to-market and collateral requirements.

\section{Mark-to-market payments}

All trades, once novated in a CCP service, are subject to daily mark-to-market (MTM) at the most recent closing price. At the time of novation, and daily until the trade has settled, the party that has lost relative to the trade price must pay an MTM payment equal to the difference between the trade price and the current market price. This payment will be transferred to the gaining party.

\section{Participant funds}

In addition to daily MTM payments, CCP participants pledge participant fund collateral to the CDS to mitigate the risks that CDS faces as a CCP. These risks are: (i), the potential for a defaulting participant to fail to pay an MTM payment owed to the CDS on default, and (ii) the replacement-cost risk on the outstanding positions in the CCP service. The MTM component of the participant fund (which is required in addition to the daily MTM payments) is designed to cover the possibility that a participant who owes a mark-to-market payment to CDS will default and not pay that amount. The outstanding position component of the participant fund is designed to cover the risk that CDS would face if a participant defaulted with outstanding transactions in a CCP service.

Two additional measures have been developed to minimize the replacement cost risk and limit losses to survivors in the CCP services resulting from another participant's default where the defaulter's own collateral was insufficient: a CCP service exposure cap and a survivor withdrawal option.

\section{Exposure cap}

The CCP exposure cap sets a predefined limit on the risk created by the outstanding positions of any single participant in all of the CCP services of which they are a member. The value against which the limit is measured is the potential replacement cost risk created by each participant in the CCP services. The replacement cost risk is measured by the collateral requirement that covers the failed trades in CNS and the unsettled future-dated and failed trades in DetNet. Each participant's risk is measured against the predetermined limit on a daily basis.

\section{Withdrawal option}

The participant withdrawal option allows participants in a CCP service to limit the loss allocation they would have been responsible for due to the future default of one or more other members of the service, by withdrawing from the service. If the participant chooses to withdraw from the service, it must first provide an additional 500 percent of its collateral requirement in that CCP service before the withdrawal is effective. The participant withdrawal option cannot be exercised to avoid an immediately available loss. However, it does limit a participant's losses in the event that another member were to default after the option had been exercised by the participant. 
Immediacy of collateral liquidation

In the CDSX, liquidity risk is created by the need to settle payment obligations on the same day that they are incurred and by the need to sell securities pledged as collateral as well as buying positions to offset a defaulter's obligations in the CCP services. The CDSX controls liquidity risk by applying haircuts to securities used as collateral, restricting the amount of ACV that can be created by certain types of securities (sector limits), restricting the eligibility of collateral in category credit ring collateral pools and participant funds, having back-up lines of credit with commercial banks, and performing stress-tests regularly.

\section{Stress-testing}

The CDS is continuing to develop its stress-testing capabilities in order to refine its estimates of the losses associated with various financial shocks, including the default of one or more participants. The results of these stress tests are used internally for risk management purposes and are also selectively disclosed to participants to help inform participants' own risk management decisions.

\section{Default process}

The CDS Participant Rules outline the grounds for suspension and the process for default management. During the processing of a suspension, the CDS allocates the suspended participant's current payment obligation to the appropriate mechanism, which in turn is responsible for paying CDS the default amount allocated to them.

The CDS initiates suspension and default procedures against a participant if they fail to fulfill any of the obligations. The same suspension and default procedures are applied regardless of the cause of the suspension.

The payment obligation in the CDSX of any suspended participant (i.e., extender of credit, settlement agent, federated participant or receiver of credit) must be replaced on the day of suspension. Settled transactions cannot be unwound during the processing of a suspension, nor can the suspended participant's payment obligation be delayed beyond the date of suspension. On the day of suspension, an alternative source of funds must be available to replace the amount that was owed to CDS by the suspended participant. The process of determining the payment obligation amount is conducted separately for each currency in which the suspended participant has an obligation owing to CDS.

If a suspended participant has outstanding CCP obligations (that is, outstanding todeliver or to receive positions in CNS or DetNet), the CDS executes close-out transactions to clear these outstanding positions. For example, if the suspended participant left a CNS outstanding to deliver position, the CDS buys or sells the securities in the market to clear the outstanding position. Any loss or gain that is generated by the execution of these close-out transactions becomes an obligation of the CCP participant fund for the service in which the outstanding position originated.

Risk management-New York Link (NYL)

The CDS and National Securities Clearing Corporation (NSCC) hold collateral that serves to cover both CDS's exposure to participants using the NYL Service and NSCC's exposure to the CDS in the event that the CDS cannot complete settlement on behalf of the NYL participants. The arrangement in place is that collateral requirements are calculated based on the risk methodology of NSCC, and knowing these requirements, the CDS collects the collateral that its participants are required to pledge to support settlement of their transactions in NSCC. The collateral pledged is held partly by the CDS and partly by NSCC.

Within NSCC, any net market loss on the close-out of guaranteed transactions of a 


\begin{tabular}{|c|c|}
\hline & $\begin{array}{l}\text { defaulting member is first to be covered by the defaulter's contribution to the NSCC } \\
\text { clearing fund plus any other collateral of the defaulter available to NSCC. Any part of } \\
\text { the loss not covered by the defaulter's collateral is borne by NSCC's surviving } \\
\text { members. } \\
\text { The CDS manages its risk to a loss allocation by NSCC by having participants using } \\
\text { the NYL Service agree to indemnify and hold harmless the CDS from and against any } \\
\text { loss, damage, cost, expense, assessment, penalty, charge, liability, or claim. In } \\
\text { particular, Rule } 4.1 .3 \text { describes the indemnity provided by participants to the CDS } \\
\text { regarding services generally. It states that each participant shall indemnify and hold } \\
\text { harmless the CDS, nominees, and all other participants and relevant parties from and } \\
\text { against any loss. } \\
\text { Multiple failures } \\
\text { CDSX is designed to fully collateralize at least the largest intraday net debit position, } \\
\text { and it also has in place risk control mechanisms to avert multiple failures before they } \\
\text { happen and to deal with them if they do. These include stringent membership } \\
\text { standards, guarantees provided by surviving members of collateral pools and } \\
\text { participant funds, as well as monitoring and early intervention by CDS, regulatory } \\
\text { authorities, and the participants themselves. }\end{array}$ \\
\hline Assessment & Observed \\
\hline Comments & $\begin{array}{l}\text { In order to further protect the CDSX from the credit and liquidity risks arising from } \\
\text { the CCP services and, as international best practice, the CCP functions should be } \\
\text { separated from the settlement and custody functions, with the CCP services being } \\
\text { provided by a distinct legal entity. }\end{array}$ \\
\hline Recommendation 10. & $\begin{array}{l}\text { Assets used to settle the cash leg of securities transactions between CSD members } \\
\text { should carry little or no credit risk. If central bank money is not used, steps must be } \\
\text { taken to protect CSD members from potential losses and liquidity pressures arising } \\
\text { from the failure of a settlement bank. }\end{array}$ \\
\hline Description & $\begin{array}{l}\text { Multi-tiered structure for cash settlement } \\
\text { Throughout the day, transactions are settled in commercial bank money provided by } \\
\text { the CDS and commercial banks. At the end of the day, the net balances between the } \\
\text { CDS and the banks are settled through the LVTS on the books of BOC. } \\
\text { The system uses a tiered structure whereby only certain designated participants can } \\
\text { participate in the Payment Exchange process with CDS. These "Designated Bankers" } \\
\text { are settlement banks eligible to act for their own account as well as on behalf of others. } \\
\text { Only Extenders of Credit or Active Federated Participants are qualified to act as } \\
\text { Designated Bankers. A participant who is not a Designated Banker must appoint one. } \\
\text { All Designated Bankers are regulated financial institutions. For the settlement of the } \\
\text { CAD, settlement banks must be members of the Canadian Payment Associations } \\
\text { (CPA's) LVTS. For the settlement of the US dollar, settlement banks must be } \\
\text { members of FedWire Funds. } \\
\text { The net settlement positions are aggregated at the settlement bank level. These } \\
\text { aggregated net settlement positions are settled with the CDS during the day. Once a } \\
\text { participant makes a payment to the CDS, that participant's settlement obligation is } \\
\text { extinguished. Similarly, once the CDS makes payment to a participant, the CDS's } \\
\text { settlement obligation vis-à-vis that participant is extinguished. The CDS must receive } \\
\text { all funds owed to it before making payments to participants. } \\
\text { CAD cash settlement }\end{array}$ \\
\hline
\end{tabular}




\begin{tabular}{|c|c|}
\hline & $\begin{array}{l}\text { Cash settlement of CAD positions towards banks in the CDSX is effected through } \\
\text { transfers on the books of the BOC at the end of the day using the LVTS. Once all pay- } \\
\text { ins are received in the CDS's settlement account at the BOC, the CDS instructs the } \\
\text { BOC to make the pay-outs to participants. } \\
\text { US dollar cash settlement } \\
\text { The cash settlement of US dollar positions in the CDSX is effected through transfers } \\
\text { on the books of a private bank (BMO Harris). In selecting its US dollar banker, the } \\
\text { CDS requires a minimum credit rating threshold of 'A' (S\&P rating) or 'A2' (Moody's } \\
\text { rating). Payment exchange involves FedWire Funds payments between CDS } \\
\text { settlement banks and CDS's US dollar banker acting as settlement agent for US dollar- } \\
\text { denominated transactions in CDSX. The gross value of US dollar transactions in the } \\
\text { CDS is about USD } 1.3 \text { billion, which results in daily net payment obligations of about } \\
\text { US dollar } \$ 520 \text { million. } \\
\text { Concentration of settlement bank risk } \\
\text { The CDS uses a single private bank as a settlement agent for the settlement of the US } \\
\text { dollar-denominated securities in CDSX. If this private bank were to fail during the } \\
\text { period in which pay-ins are received but have not yet been paid out, the CDS would } \\
\text { still be responsible for making the pay-outs. The CDS would generally pass these } \\
\text { losses on to its members. The potential credit losses may represent a systemic risk for } \\
\text { CDS, although the relative size of US dollar-denominated securities remains relatively } \\
\text { small for the time being. Furthermore, there may be some US dollar liquidity pressures } \\
\text { associated with the failure of the US dollar settlement agent. } \\
\text { Same day funds } \\
\text { The proceeds of securities settlements can be used as soon as they are credited to the } \\
\text { participants' cash/securities accounts. Participants are also required to transfer the cash } \\
\text { and securities to their clients on the same day. }\end{array}$ \\
\hline Assessment & $\begin{array}{l}\text { Observed for Canadian dollar settlement. } \\
\text { Non-observed for US dollar settlement. }\end{array}$ \\
\hline Comments & $\begin{array}{l}\text { For the full observance of this recommendation, the CDS needs to reduce the current } \\
\text { concentration of settlement cash for US dollar dominated securities on a single } \\
\text { settlement bank. The CDS might explore the possibility of becoming a direct } \\
\text { member of Fedwire or having access to US dollar central bank money through the } \\
\text { Bank of Canada. } \\
\text { The CDS practice of taking on credit exposure as a CCP should be more transparent. }\end{array}$ \\
\hline Recommendation 11. & $\begin{array}{l}\text { Sources of operational risk arising in the clearing and settlement process should be } \\
\text { identified and minimized through the development of appropriate systems, controls } \\
\text { and procedures. Systems should be reliable and secure, and have adequate, scalable } \\
\text { capacity. Contingency plans and back-up facilities should be established to allow for } \\
\text { timely recovery of operations and completion of the settlement process. }\end{array}$ \\
\hline Description & $\begin{array}{l}\text { Identification and management of operational risk } \\
\text { The CDS has developed an operational risk control model that employs service level } \\
\text { standards, which cover the depository, clearing, settlement, and ancillary services, and } \\
\text { which are based on input from its participants. The standards are intended to serve as } \\
\text { targets for the system and focus not only on the reliability of CDSX but also on the } \\
\text { targeted level and quality of the customer services supported within the CDSX } \\
\text { platform. These standards are consistently met through regular monitoring and testing. } \\
\text { The CDS, through its internal audit function, performs more than } 20 \text { disaster recovery } \\
\text { tests throughout each year. In 2006, no significant problems were encountered through } \\
\text { testing. The CDS reports on these tests and on its compliance with these standards in }\end{array}$ \\
\hline
\end{tabular}


its quarterly newsletter.

The internal risk management department at CDS, along with internal risk and operations committees, an external risk advisory committee (composed of CDS members and regulators) and the board's audit/risk committee develop, monitor, and update the standards and oversee their compliance.

\section{Contingency plans and back up facilities}

The CDS completed a business continuity planning review in 2005 and began implementing some changes to its contingency procedures that would decentralize some of their core services. To avoid serious disruptions, it distributed key service operations between Toronto, Montreal, and Vancouver, with at least two locations capable of providing all its core services system-wide. This was completed by June 2006.

As for CDSX, the operating facilities involve two independent central operating sites, with back-up facilities in each, and tertiary contingency arrangements (such as secure facsimile procedures and book-based transfers) in the unlikely event of simultaneous outages of both primary and back-up sites. Independence of the operating sites refers to remote physical locations, close enough to allow personnel transfer on short notice with negligible failover time but distant enough to ensure security from localized physical infrastructure disasters (such as electrical grid failures, floods, fires, or terrorist events). Planned failover times from primary to secondary sites are well within the two-to-four hour standards used internationally.

The CDS has business resumption plans (BRPs) for key systems. The plans, which are updated semi-annually, provide for crisis management, communication, and recovery teams. The latest disaster recovery test to date was in mid-November 2005, with full success against target objectives. All failover and failback two-and-four hour recovery objectives between primary and back-up sites were easily met in an actual processing environment in which markets were open (although banks were closed). There was neither loss of data nor any meaningful disruption in services. A second overnight exercise in May 2006 involving all CDSX clearing and settlement applications was equally successful. All recovery requirements were achieved in just under the 2-hour target recovery time and all 4-hour requirements were achieved in less than 3 hours. The simulated overnight batch processing execution was fully completed on time.

\section{$B C P$ coordination with related systems}

CDSX is linked to other settlement systems for payment exchange, notably the LVTS and the BOC's Collateral Value and Transfer System (CVTS) and its Account Services and Payments (ASAP) system. Accordingly, the CDS, the CPA, and the BOC established a Joint Business Continuity Planning Group in 2003 to identify operational risks in the core systems of these organizations that could prevent same-day cash settlement and their next-day readiness to operate. The Joint BCP Group is required to assess the extent of the threat of these operational risks, develop risk prevention and operational recovery strategies, and propose forward-looking initiatives to mitigate the future threat of these risks.

\section{Protection of data communication}

To protect against data loss, the CDS has backups of all computer files, has secure offsite data storage, and uses data mirroring in the back-up systems. The CDS monitors system stress in key systems for early warning of potential operational problems that may arise. 


\begin{tabular}{|c|c|}
\hline & $\begin{array}{l}\text { annual average), operational reliability ( } 99.4 \text { percent annual average) and payment } \\
\text { exchange ( } 99.6 \text { percent annual average). In } 2006 \text {, each of these target levels was } \\
\text { surpassed. Actual network availability was } 99.9 \text { percent of required time, operational } \\
\text { reliability at } 99.8 \text { percent, and payment exchange at } 100 \text { percent of required time. } \\
\text { In terms of scalability, the CDS targets its actual capacity utilization at about } 50 \\
\text { percent of fully available operating capacity as defined by a rolling } 20 \text {-day average of } \\
\text { volume. It aims to produce processing improvements and design enhancements to } \\
\text { alleviate potential bottlenecks for the operating capacity of the core systems, including } \\
\text { CDSX, without substantial hardware upgrades. Indeed, tests on a number of such } \\
\text { changes made in } 2006 \text { indicated that they almost doubled the peak intra-day capacity } \\
\text { of the existing technology platform. } \\
\text { Development and procurement } \\
\text { Some of the processing operations for CDSX are out-sourced or co-sourced to third- } \\
\text { party service providers. The CDS service agreements with third-party service } \\
\text { providers require compliance with the relevant operational risk controls, service level } \\
\text { standards, and contingency arrangements in CDS's risk model for CDSX and its } \\
\text { service agreements with the CDS members and CDSX participants. The CDS manages } \\
\text { these outsourcing agreements actively. } \\
\text { External audits } \\
\text { An annual independent audit of operational risk controls (a } 5970 \text { audit) is performed } \\
\text { by KPMG LLP to assess CDS's risk-control procedures. The most recent annual audit } \\
\text { for the year ending July } 31,2006 \text { found that controls were appropriately designed and } \\
\text { effective. }\end{array}$ \\
\hline Assessment & Observed \\
\hline Comments & \\
\hline Recommendation 12. & $\begin{array}{l}\text { Entities holding securities in custody should employ accounting practices and } \\
\text { safekeeping procedures that fully protect customers' securities. It is essential that } \\
\text { customers' securities be protected against the claims of a custodian's creditors. }\end{array}$ \\
\hline Description & $\begin{array}{l}\text { The CDS operates an "indirect holding" system, where securities are registered in the } \\
\text { name of the broker/dealer or custodian, through nominee accounts, rather than in the } \\
\text { name of the end beneficiary. The broker/dealer or custodian is responsible for the } \\
\text { management of securities holdings in their individual client accounts, again through } \\
\text { book-entry systems. } \\
\text { Account segregation } \\
\text { Asset holdings are protected through account segregation: CDS participants need to } \\
\text { separate between their own holdings and customers' holdings. In addition, there are } \\
\text { separate electronic ledger accounts for securities pledged to the CDS and assets of } \\
\text { participants held by the CDS in the depository. As indicated in Recommendation 1, the } \\
\text { PCSA and the PPSA protect assets held by CDS for participants against liens by } \\
\text { creditors of CDS. } \\
\text { Securities custody and transfer safety arrangements } \\
\text { To protect participant's securities against loss and inappropriate disposition, the CDS } \\
\text { has established on-site security standards and guidelines for each depository site. } \\
\text { These involve physical security personnel and devices, electronic security and } \\
\text { monitoring, and personnel access and identification requirements. Access to inventory } \\
\text { sites is restricted and closely monitored. Inventory handling procedures are updated } \\
\text { and closely inspected for immediate problem resolution. Site security is subject to } \\
\text { periodic checks and regular maintenance (for example, periodic lock changes). }\end{array}$ \\
\hline
\end{tabular}


Securities certificates are housed in vaults in the CDS. Registered securities are held in the CDS's nominee name in non-negotiable form. The market value for immobilized single security certificates is capped at $\$ 50$ million Canadian to limit the value of certificate losses.

Physical transfer of security certificates across regional offices for safekeeping or delivery involves extensive documentation and controls. Transfer is through armored courier services with strict transfer procedures and controls.

\section{Inventory control and reconciliation}

Verification of the inventory of physical certificates and reconciliation with securities book-entry ledger accounts is performed on an on-going basis. Custodians, holding both physical securities and dematerialized securities, provide the CDS with inventory listings monthly, which are checked against the CDS internal reports. CDSX participants' electronic securities ledger accounts are also reconciled with the CDS reports of internal inventory holdings and external custodian holdings. Custodians transfer an electronic inventory file to the CDS through CDSX on a daily basis for CDSX automated reconciliation. Exceptions are documented and resolved using standard procedures and guidelines. Reports on participant ledger holdings against CDS (internal and external) inventory holdings are produced each night, with discrepancies noted and resolved. If resolution is not timely, follow-up procedures to escalate the process are triggered through the automated reports.

\section{Audits of inventory management procedures}

In addition to internal audits of performance and procedures, the inventory management process is subject to an annual external audit. The CDS is also subject to audits by the OSC and the autorité des marchés financiers (AMF) for depository services.

\section{CDS protection against liability loss}

In addition to controls to manage custody risk, the CDS also has acquired specialized insurance against financial liability in the performance of its custody services. As part of its operational risk insurance, the CDS purchases protection against the risk of loss or damage to securities from fraud, theft, destruction, or disappearance. In addition, the CDS purchases insurance for loss from errors and omissions, general liability, and direct damage to real property and computer equipment. In the event that depository assets are lost or damaged as the result of an insured peril, the CDS limits its liability to the net amount recovered from insurers, plus any amount agreed to by the Board of Directors, which may be available through the corporation's reserves.

If the CDS uses a third-party custodian to hold participants' assets (as for cross-border functions), the CDS adequately transfers responsibility for losses to the agent being used and verifies that the CDS board-approved standards for security and insurance are maintained. The CDS selects as domestic and foreign custodians: (i) the BOC or another central bank of a country recognized by Canada; (ii) a regulated securities depository or clearing agency; or, (iii) a regulated trust or banking firm (or whollyowned subsidiary) in good regulatory standing, subject to minimum capital and credit rating requirements.

\section{Supervision and regulation}

As noted in Recommendations 1 and 6, the CDS is subject to regulation of its depository and transfer functions by the OSC and the AMF. 


\begin{tabular}{|c|c|}
\hline Comments & $\begin{array}{l}\text { In order to reduce the custody risk, the CDS should eliminate the circulation of } \\
\text { physical securities through its regional offices by immobilizing or, preferably, } \\
\text { dematerializing them. }\end{array}$ \\
\hline Recommendation 13. & $\begin{array}{l}\text { Governance arrangements for CSDs and central counterparties should be designed to } \\
\text { fulfill public interest requirements and to promote the objectives of owners and users. }\end{array}$ \\
\hline Description & 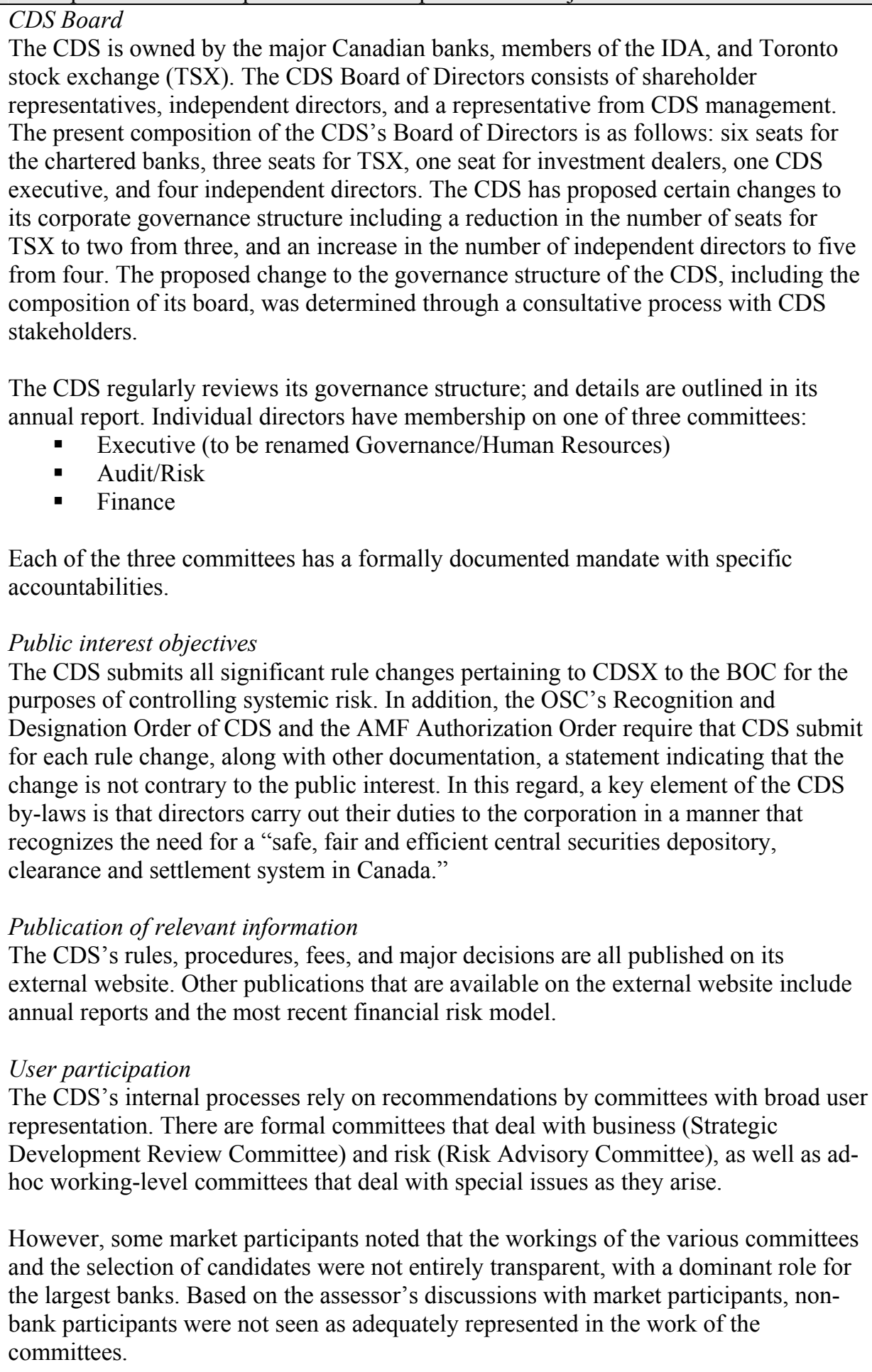 \\
\hline
\end{tabular}




\begin{tabular}{|c|c|}
\hline Assessment & Observed \\
\hline Comments & $\begin{array}{l}\text { The workings of the committees set up by the CDS could be made more transparent } \\
\text { by taking greater account of the interests of non-bank participants. }\end{array}$ \\
\hline Recommendation 14. & $\begin{array}{l}\text { CSDs and central counterparties should have objective and publicly disclosed criteria } \\
\text { for participation that permit fair and open access. }\end{array}$ \\
\hline Description & 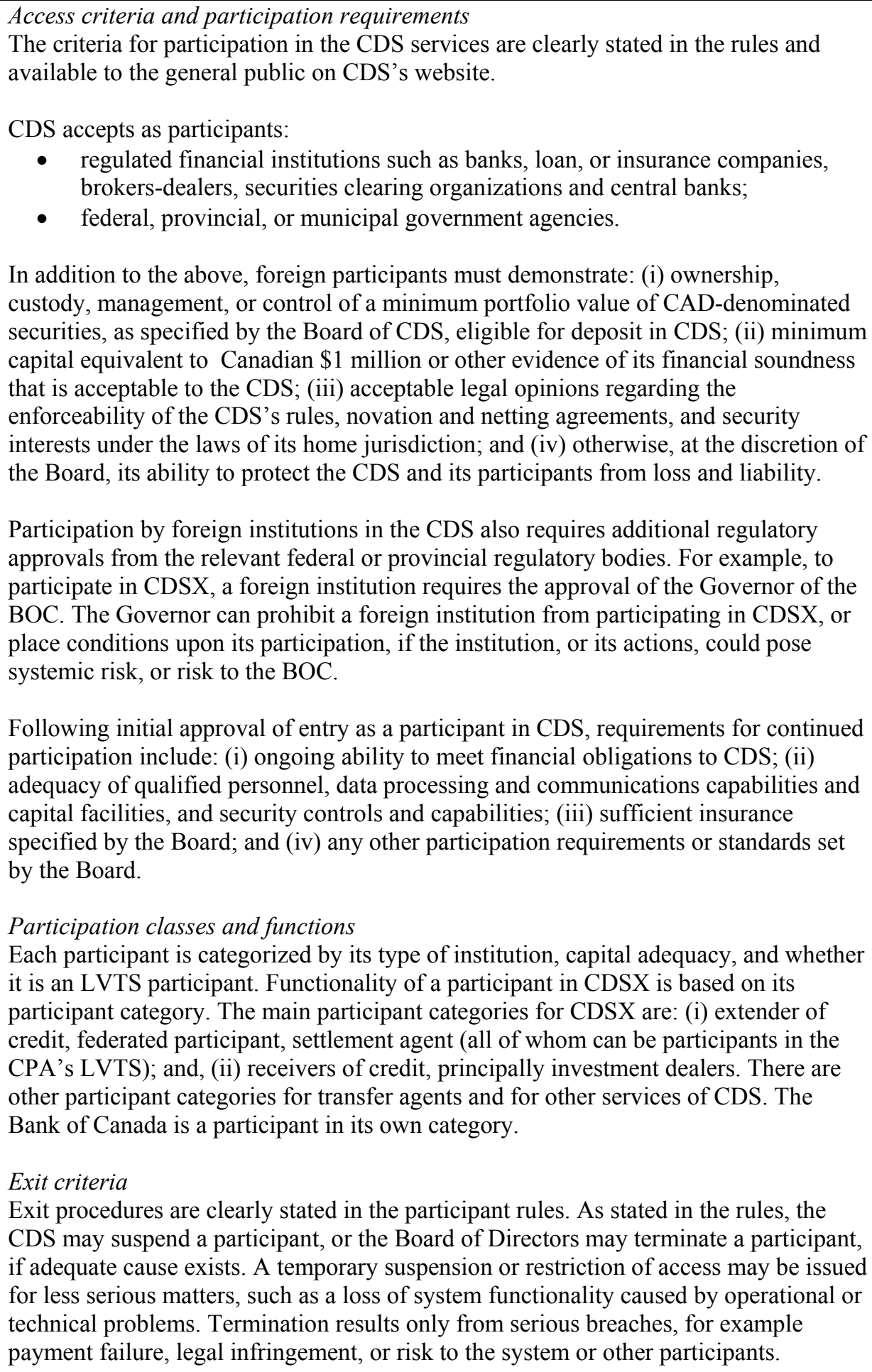 \\
\hline
\end{tabular}




\begin{tabular}{|c|c|}
\hline & $\begin{array}{l}\text { For participants who are IDA members, the CDS has signed a Memorandum of } \\
\text { Understanding with the IDA under which the IDA is required to inform the CDS when } \\
\text { a member is in early warning. }\end{array}$ \\
\hline Assessment & Observed \\
\hline \multicolumn{2}{|l|}{ Comments } \\
\hline Recommendation 15. & $\begin{array}{l}\text { While maintaining safe and secure operations, securities settlement systems should be } \\
\text { cost-effective in meeting the requirements of users. }\end{array}$ \\
\hline Description & 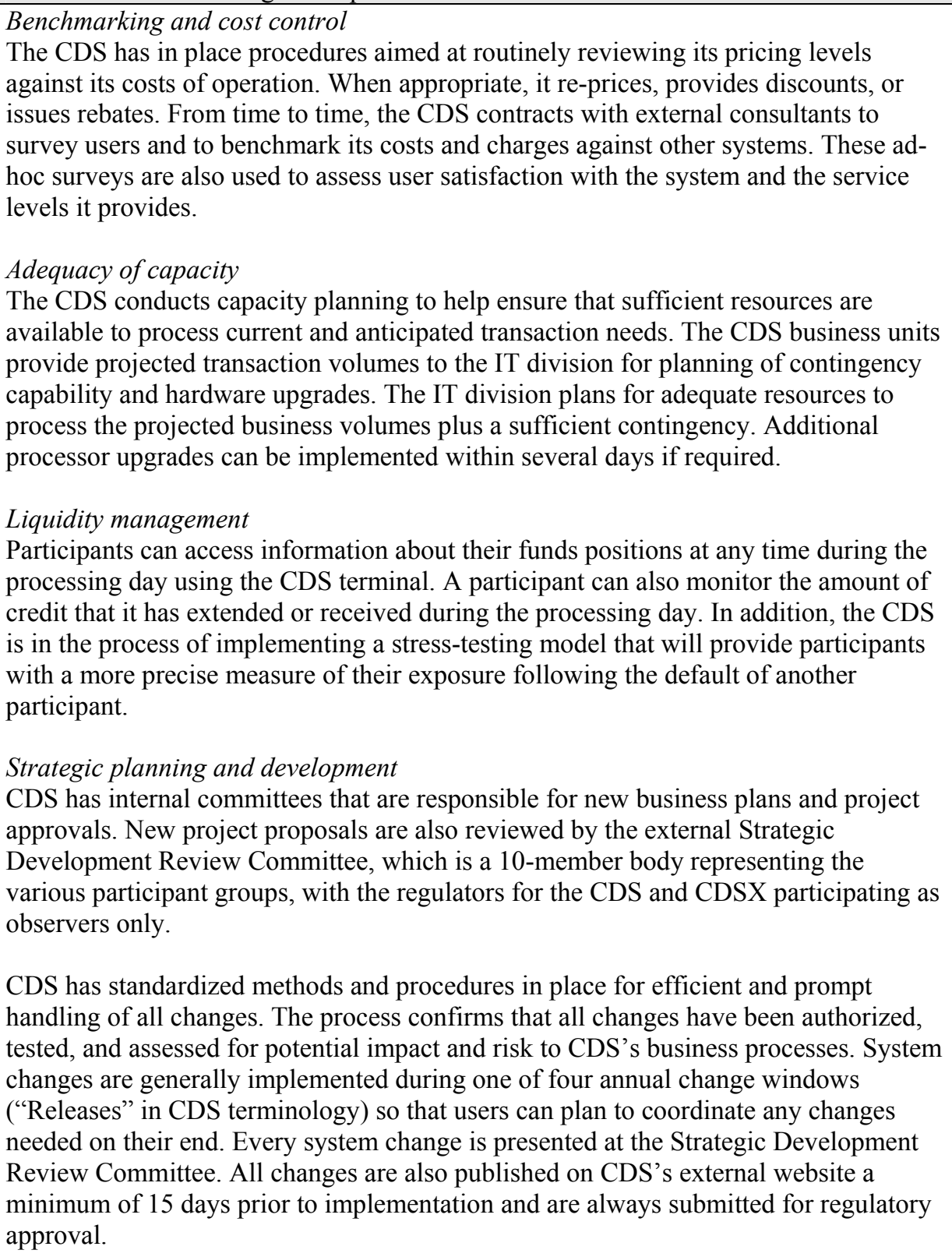 \\
\hline Assessment & Observed \\
\hline \multicolumn{2}{|l|}{ Comments } \\
\hline Recommendation 16. & $\begin{array}{l}\text { Securities settlement systems should use or accommodate the relevant international } \\
\text { communication procedures and standards in order to facilitate efficient settlement of }\end{array}$ \\
\hline
\end{tabular}




\begin{tabular}{|c|c|}
\hline & cross-border transactions. \\
\hline Description & $\begin{array}{l}\text { The CDS uses a proprietary communication system. For cross-border transactions, the } \\
\text { CDS uses internationally recognized standards based on Society for Worldwide } \\
\text { Interbank Financial Telecommunication (SWIFT's) new messaging formats that } \\
\text { contain reusable blocks of information and minimize rekeying of information. The } \\
\text { international securities identification numbering process (ISIN) ISO } 6166 \text { is also used. } \\
\text { Other means of communication (telex, fax, and mail) are only accepted in exceptional } \\
\text { situations (contingency, recognized market practice). } \\
\text { For domestic transactions, the CDS is still using an old-fashioned message format, } \\
\text { based on outdated software, which does not provide flexibility to participants to } \\
\text { process the information and data. }\end{array}$ \\
\hline Assessment & Observed \\
\hline Comments & $\begin{array}{l}\text { The CDS may wish to adopt a modern messages interface that is more user-friendly } \\
\text { and meets the needs of participants. }\end{array}$ \\
\hline Recommendation 17. & $\begin{array}{l}\text { CSDs and central counterparties should provide market participants with sufficient } \\
\text { information for them to accurately identify the risks and costs associated with using } \\
\text { the CSD or central counterparty services. }\end{array}$ \\
\hline Description & $\begin{array}{l}\text { Availability of rules, regulations etc. } \\
\text { Laws, regulations, system rules, and fees are part of the contractual agreements that } \\
\text { are signed by participants. In particular, participants' rights, obligations, and costs are } \\
\text { defined in these documents, which are available on the CDS website. } \\
\text { CPSS/IOSCO disclosure framework } \\
\text { The CDS has completed and disclosed its responses to the CPSS-IOSCO Disclosure } \\
\text { Framework (CPSS-IOSCO 1997). The responses are posted on the Website of the } \\
\text { CPSS. The CDS also publishes on its website: (i) its full risk model; and (ii) an annual } \\
\text { update to its report on internal controls. } \\
\text { Financial risk monitoring and surveillance report } \\
\text { On a monthly basis, the CDS distributes a report to its participants, Risk/Audit } \\
\text { Committee and Risk Advisory Committee, which provides statistics on the } \\
\text { performance of the various risk controls in CDSX and various risk measures. This } \\
\text { report includes back-testing results for collateralization and disclosure of the size of } \\
\text { uncollateralized losses from default simulations. This report is revised regularly based } \\
\text { on feedback from participants. } \\
\text { Frequency of updates } \\
\text { The CDS actively updates its website for material changes to rules, procedures, and } \\
\text { practices. Through the year, it also updates its documentation on a regular schedule } \\
\text { with updated information posted promptly to its website. }\end{array}$ \\
\hline Assessment & Observed \\
\hline \multicolumn{2}{|l|}{ Comments } \\
\hline Recommendation 18. & $\begin{array}{l}\text { Securities settlement systems should be subject to regulation and oversight. The } \\
\text { responsibilities and objectives of the securities regulator and the central bank with } \\
\text { respect to SSSs should be clearly defined, and their roles and major policies should be } \\
\text { publicly disclosed. They should have the ability and resources to perform their } \\
\text { responsibilities, including assessing and promoting implementation of these } \\
\text { recommendations. They should cooperate with each other and with other relevant }\end{array}$ \\
\hline
\end{tabular}




\begin{tabular}{|c|c|}
\hline & authorities. \\
\hline Description & 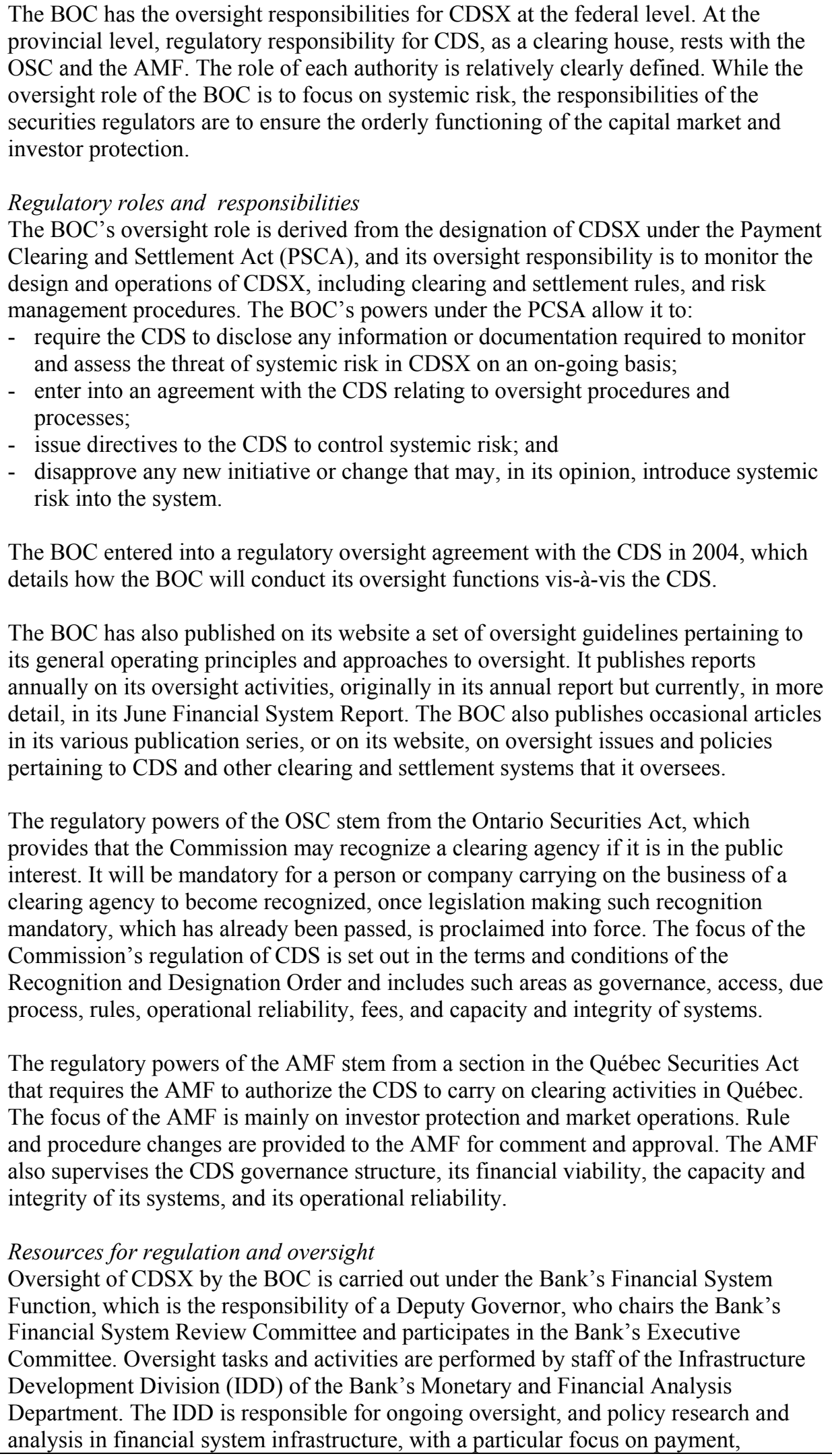 \\
\hline
\end{tabular}




\begin{tabular}{|c|c|}
\hline & 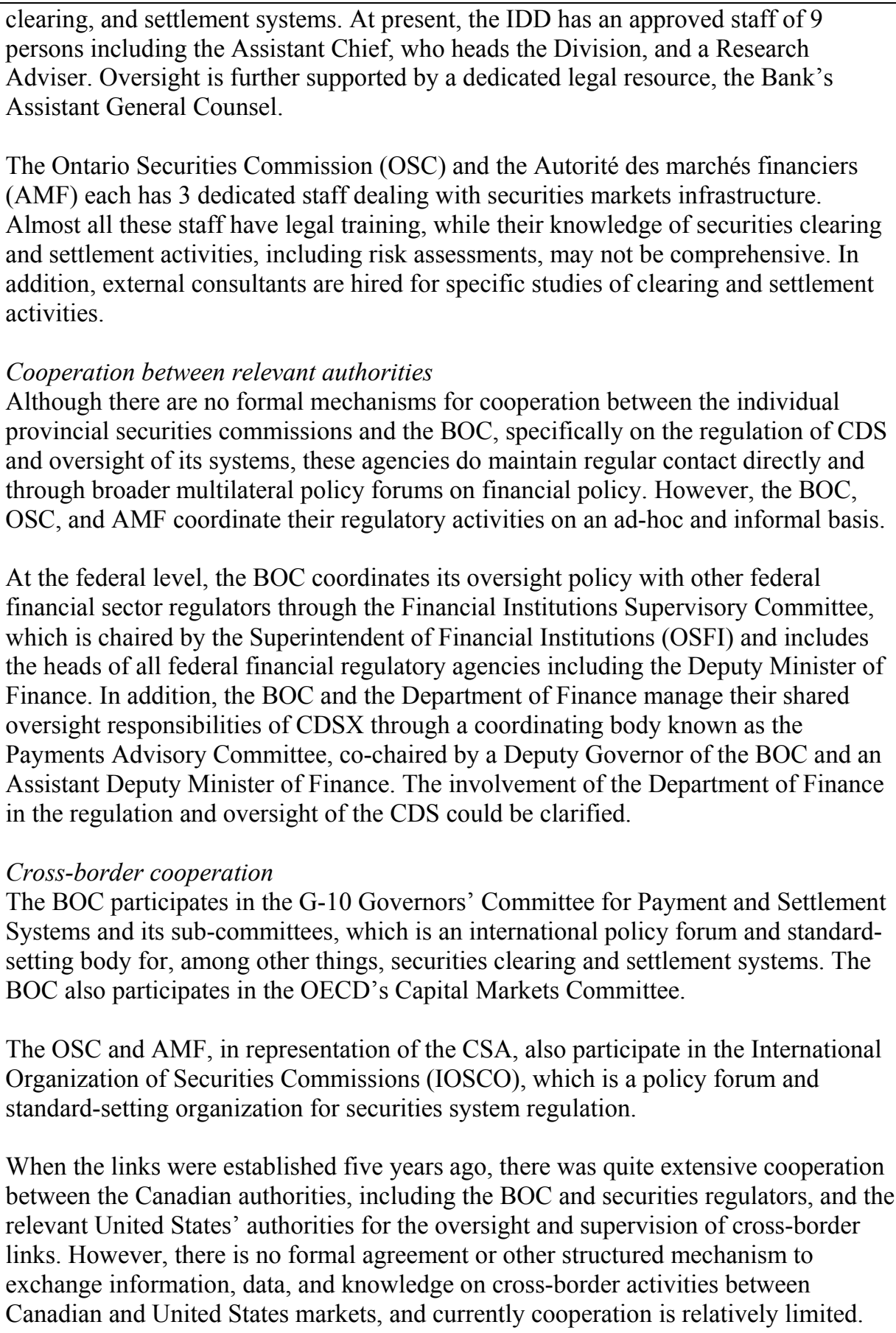 \\
\hline Assessment & Observed \\
\hline
\end{tabular}




\begin{tabular}{|c|c|}
\hline Comments & $\begin{array}{l}\text { Cooperation between the BOC and the provincial securities regulators should be } \\
\text { strengthened and formalized. } \\
\text { The same comment applies to cooperation between the Canadian authorities and the } \\
\text { relevant United States authorities for the cross-border activities through the links } \\
\text { between Canada and the United States. A key objective is to make the regulation } \\
\text { and oversight of clearing and settlement activities more effective and transparent } \\
\text { for both service providers and market participants. In this regard, the BOC has been } \\
\text { preparing a review of the oversight of cross-border clearing and settlement links } \\
\text { more generally. This work, while still in draft form, among other things } \\
\text { recommends regular consultation with relevant foreign regulators. }\end{array}$ \\
\hline Recommendation 19. & $\begin{array}{l}\text { CSDs that establish links to settle cross-border trades should design and operate such } \\
\text { links to reduce effectively the risks associated with cross-border settlement. }\end{array}$ \\
\hline Description & 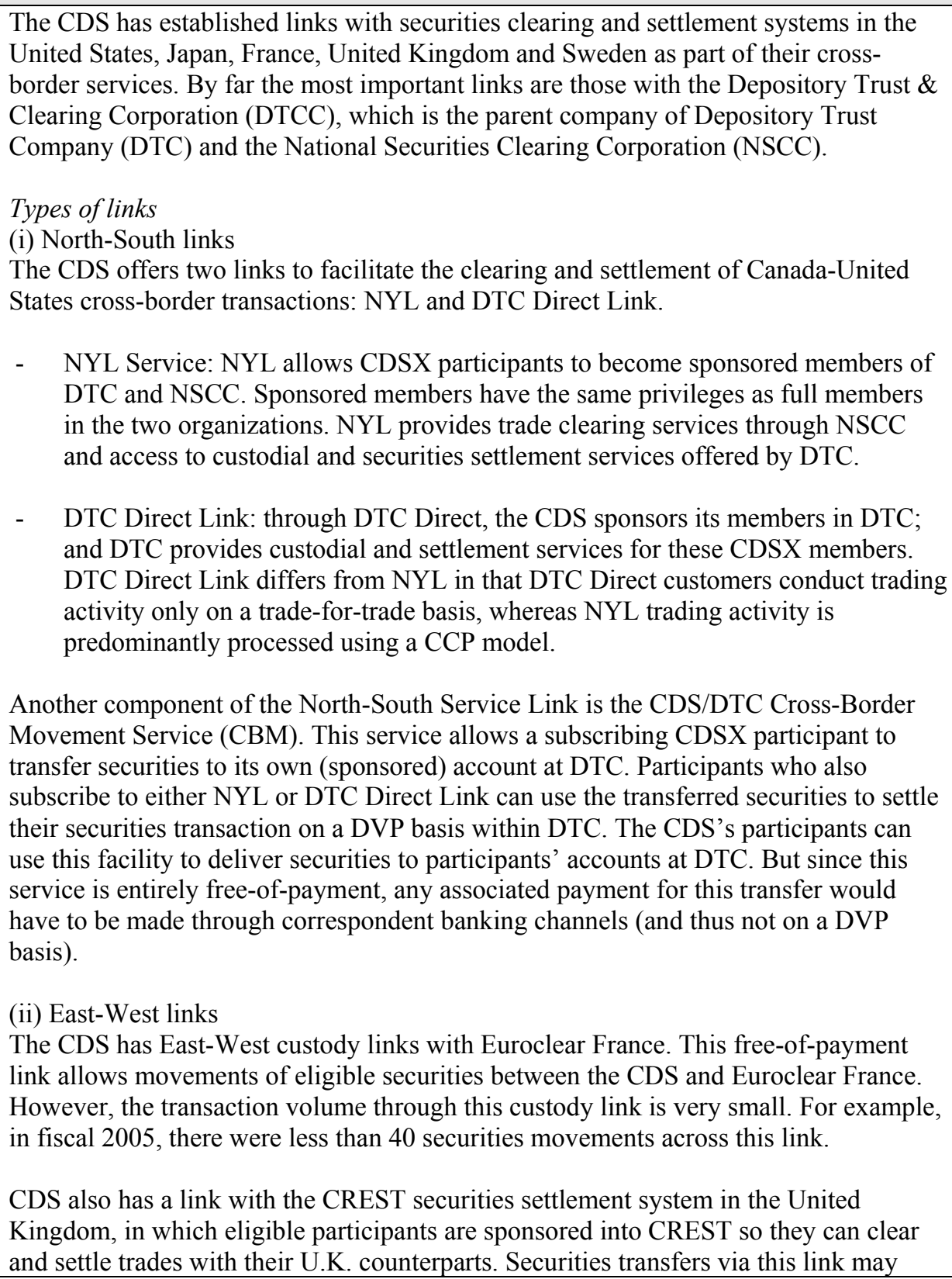 \\
\hline
\end{tabular}


occur either free-of-payment or DVP against funds denominated in GBP, EUR, or U.S. dollar.

The CDS has an indirect link with the Swedish central securities depository (VPC). The CDS settlement agent is the Skandinaviska Enskilda Banken AB. This free-ofpayment link facilitates the movement of eligible securities. Participants may move securities eastbound (i.e., from Canada to Sweden) and westbound (i.e., from Sweden to Canada). Currently, only one equity issue (Boliden), cross listed on the Toronto Stock Exchange and on the Swedish Stock Exchange, is eligible for this link.

(iii) Foreign settlement systems linked to CDSX

The DTC CAD settlement link allows DTC participants to settle CAD transactions directly with DTC. To implement the link, DTC processes Canadian dollar transactions through its omnibus account at CDS on behalf of its participants. An endof-day settlement process is used to settle the CAD obligations associated with this link via a CAD settlement bank, that participates in the end-of-day CDSX payment exchange.

The Japanese CSD also has established a CDSX account to facilitate a cross-border free-of-payment link for its participants.

\section{Risk analysis and risk management of links}

Current and potential cross-border links are examined to determine whether the link represents unacceptable financial risks to CDS that operates CDSX, or would cause CDSX to no longer meet minimum standards.

As a result of the analysis of its cross-border links with DTCC, CDS terminated a link that had been previously used. The American and Canadian Connection for Efficient Securities Settlement (ACCESS) was closed effective January 31, 2006 as a result of a 2005 assessment of CDS's cross-border services. Sponsored participant models (such as NYL), not an omnibus account model (such as ACCESS), are more consistent with participant requirements and CDS's risk and operational strategies. In a sponsored account arrangement, CDSX participants are identified individually in DTC's member directory and have individual accounts. In an omnibus account arrangement, such as the now terminated arrangement for ACCESS, CDS would hold a single account in DTC on behalf of CDSX members, thus leaving CDS potentially liable to CDSX participant obligations to DTC and vice versa.

As noted, the East-West links involving CDS are essentially cross-border custody arrangements, which follow the same custody risk controls outlined in Recommendation 12.

\section{Delivery versus payment}

The DVP nature of cross-border links relates to the settlement process in each of the linked systems. CDSX, as noted, operates on a DVP basis with intraday finality of settlement (see Recommendation 8). DTC operates on a DVP basis as well but without full certainty of intra-day finality. This means that securities can be delivered to CDS and booked on the accounts of its customers without achieving settlement finality in DTC. However, even if such deliveries were permitted, any resulting risk to CDS is sufficiently mitigated, because of the general risk controls that CDS has in place. In the event that DTC required the replacement of securities imported into CDS, the costs associated with replacing the securities in DTC would be borne by the defaulting participant sponsored into DTC by CDS, and by surviving CDS-sponsored participants, in accordance with established CDS rules. 


\begin{tabular}{|c|c|}
\hline & $\begin{array}{l}\text { For the settlement of the cash leg in DTC, the CDS uses a single private bank as a } \\
\text { settlement agent. It is also the same bank used for settling the US dollar-denominated } \\
\text { securities within CDS. If the private bank were to fail, the CDS would still be } \\
\text { responsible for making the payment to its customers. This means that CDS is exposed } \\
\text { to potential credit losses. } \\
\text { CDS participation in NSCC } \\
\text { The CDS, as a participant in NSCC, shares the loss allocations in NSCC in the event } \\
\text { of default members within NSCC. Within NSCC, any net market loss on the close-out } \\
\text { of guaranteed transactions of a defaulting member is first to be covered by the } \\
\text { defaulter's contribution to the NSCC clearing fund plus any other collateral of the } \\
\text { defaulter available to NSCC. Any part of the loss not covered by the defaulter's } \\
\text { collateral is borne by NSCC's surviving members. The CDS manages its risk to a loss } \\
\text { allocation by NSCC through having participants using the NYL Service agree to } \\
\text { indemnify and hold harmless the CDS from and against any losses. This is in line with } \\
\text { its general indemnification policy, which covers all its activities. } \\
\text { Furthermore, the CDS and NSCC hold collateral that serves to cover both CDS's } \\
\text { exposure to participants using the NYL Service and NSCC's exposure to the CDS in } \\
\text { the event that CDS cannot complete settlement on behalf of the NYL participants. The } \\
\text { collateral requirements are calculated based on the risk methodology of NSCC, and } \\
\text { knowing these requirements, the CDS collects the collateral that CDS participants are } \\
\text { required to pledge to support settlement of their transactions in NSCC. The collateral } \\
\text { pledged is held partly by the CDS and partly by NSCC. } \\
\text { Although the links are established by CDS and not CDSX, any disruption that } \\
\text { financial distress may cause CDS due to the links with DTC and NSCC will directly } \\
\text { affect the functioning of the CDSX. }\end{array}$ \\
\hline Assessment & $\begin{array}{l}\text { Observed for the links to United Kingdom, France, Japan and Sweden } \\
\text { Non-observed for the links to DTC }\end{array}$ \\
\hline Comments & $\begin{array}{l}\text { For the observance of this recommendation, the CDS should not allow the transfer } \\
\text { of securities, delivered through the DTC links, to its participants until these } \\
\text { securities reach settlement finality in the DTC system. Furthermore, the CDS needs } \\
\text { to reduce the concentration on a single bank for the settlement of the cash leg in } \\
\text { DTC. }\end{array}$ \\
\hline
\end{tabular}


Table 2. Summary Observance of CDSX of the CPSS-IOSCO Recommendations for
Securities Settlement Systems

\begin{tabular}{|c|c|c|}
\hline Responsibility & Grading & Comments \\
\hline \multicolumn{3}{|l|}{ Legal risk } \\
\hline $\begin{array}{l}\text { 1. Securities settlement systems should have a well- } \\
\text { founded, clear and transparent legal basis in the } \\
\text { relevant jurisdiction. }\end{array}$ & $\mathrm{O}$ & $\begin{array}{l}\text { The design and operations of the CDS are covered by } \\
\text { a solid legal basis; and the contractual arrangements } \\
\text { between the CDS and its participants are fully } \\
\text { enforceable. The regulatory framework is clear and } \\
\text { transparent to market participants. }\end{array}$ \\
\hline \multicolumn{3}{|l|}{ Pre-settlement risk } \\
\hline $\begin{array}{l}\text { 2. Confirmation of trades between market } \\
\text { participants should occur as soon as possible after } \\
\text { trade execution, but no later than the trade date } \\
(\mathrm{T}+0) \text {. Where confirmation of trades by indirect } \\
\text { market participants (such as institutional investors) } \\
\text { is required, it should occur as soon as possible after } \\
\text { trade execution, preferably on } \mathrm{T}+0 \text {, but no later } \\
\text { than } \mathrm{T}+1 \text {. }\end{array}$ & $\mathrm{O}$ & $\begin{array}{l}\text { Trade confirmation for regulated markets occurs the } \\
\text { same day between direct participants, and the next } \\
\text { day for indirect participants. For OTC transactions, } \\
\text { the market convention is to confirm the trade on the } \\
\text { same day. }\end{array}$ \\
\hline $\begin{array}{l}\text { 3. Rolling settlement should be adopted in all } \\
\text { securities markets. Final settlement should occur no } \\
\text { later than } \mathrm{T}+3 \text {. The benefits and costs of a } \\
\text { settlement cycle shorter than } \mathrm{T}+3 \text { should be } \\
\text { assessed. }\end{array}$ & $\mathrm{O}$ & $\begin{array}{l}\text { Trade transactions are settled on a rolling basis for } \\
\text { transaction on the exchanges. The settlement cycle is } \\
T+3 \text { for equities and } T+0, T+2 \text { or } T+3 \text { for debt } \\
\text { instruments. The settlement date for OTC } \\
\text { transactions is negotiable, but the current convention } \\
\text { is to follow the settlement cycles of traded } \\
\text { instruments. }\end{array}$ \\
\hline $\begin{array}{l}\text { 4. The benefits and costs of a central counterparty } \\
\text { should be assessed. Where such a mechanism is } \\
\text { introduced, the central counterparty should } \\
\text { rigorously control the risks it assumes. }\end{array}$ & BO & $\begin{array}{l}\text { CDS acts as CCP for the cash leg of all securities } \\
\text { transactions and also on the securities leg of } \\
\text { transactions settled in the net settlement procedures. } \\
\text { However, the CDS acts as CCP at the date of } \\
\text { settlement for the majority of the transactions } \\
\text { (measured by number of transactions). This means } \\
\text { that the participants are facing counterparty risk from } \\
\text { the time of trade execution until novation occurs, } \\
\text { which can be as long as T+3. According to } \\
\text { international best practice, the CCP assumes its } \\
\text { responsibility immediately after the trade is } \\
\text { executed. } \\
\text { No explicit cost-benefit analysis has been done for } \\
\text { introducing a CCP for trade-for-trade (TFT) } \\
\text { transactions. } \\
\text { The risk management procedures of the CDS as a } \\
\text { CCP have not yet been assessed against the } \\
\text { CPSS/IOSCO Recommendations for CCP. However, } \\
\text { CDS did complete a self-assessment against these } \\
\text { recommendations. }\end{array}$ \\
\hline
\end{tabular}




\begin{tabular}{|c|c|c|}
\hline Responsibility & Grading & Comments \\
\hline $\begin{array}{l}\text { 5. Securities lending and borrowing (or repurchase } \\
\text { agreements and other economically equivalent } \\
\text { transactions) should be encouraged as a method for } \\
\text { expediting the settlement of securities transactions. } \\
\text { Barriers that inhibit the practice of lending } \\
\text { securities for this purpose should be removed. }\end{array}$ & $\mathrm{O}$ & $\begin{array}{l}\text { The CDS does not provide a securities lending } \\
\text { facility to its participants. However, analysis by CDS } \\
\text { suggests that no business case exists to support the } \\
\text { development of such a facility. } \\
\text { There are no specific barriers that inhibit the practice } \\
\text { of lending securities. }\end{array}$ \\
\hline \multicolumn{3}{|l|}{ Settlement risk } \\
\hline $\begin{array}{l}\text { 6. Securities should be immobilized or } \\
\text { dematerialized and transferred by book entry in } \\
\text { CSD to the greatest extent possible. }\end{array}$ & $\mathrm{O}$ & $\begin{array}{l}\text { The great majority of securities issued in Canada are } \\
\text { either dematerialized or immobilized in CDS. } \\
\text { Increasing the share of dematerialized securities } \\
\text { would significantly reduce costs and increase the } \\
\text { efficiency of settlement and custody. }\end{array}$ \\
\hline $\begin{array}{l}\text { 7. Securities settlement systems should eliminate } \\
\text { principal risk by linking securities transfers to } \\
\text { funds transfers in a way that achieves delivery } \\
\text { versus payment. }\end{array}$ & $\mathrm{O}$ & $\begin{array}{l}\text { The CDS provides a DVP facility for the execution } \\
\text { of settlement. }\end{array}$ \\
\hline $\begin{array}{l}\text { 8. Final settlement on a DVP basis should occur no } \\
\text { later than the end of the settlement day. Intra-day or } \\
\text { real-time finality should be provided where } \\
\text { necessary to reduce risks. }\end{array}$ & $\mathrm{O}$ & $\begin{array}{l}\text { The CDS provides both intraday and end-of-day } \\
\text { settlement finality. }\end{array}$ \\
\hline $\begin{array}{l}\text { 9. CSDs that extend intraday credit to participants, } \\
\text { including CSDs that operate net settlement } \\
\text { systems, should institute risk controls that, at a } \\
\text { minimum, ensure timely settlement in the event } \\
\text { that the participant with the largest payment } \\
\text { obligation is unable to settle. The most reliable set } \\
\text { of controls is a combination of collateral } \\
\text { requirements and limits. }\end{array}$ & $\mathrm{O}$ & $\begin{array}{l}\text { The CDS's settlement and custody functions are } \\
\text { integrated with its CCP function. This means that the } \\
\text { settlement and custody functions are exposed to the } \\
\text { credit and liquidity risks arising from CCP activities, } \\
\text { although these risks are mitigated by the CCP's } \\
\text { current risk management procedures. }\end{array}$ \\
\hline $\begin{array}{l}\text { 10. Assets used to settle the cash leg of securities } \\
\text { transactions between CSD members should carry } \\
\text { little or no credit risk. If Central Bank money is not } \\
\text { used, steps must be taken to protect CSD members } \\
\text { from potential losses and liquidity pressures arising } \\
\text { from the failure of a settlement bank. }\end{array}$ & $\begin{array}{l}\text { O } \\
\text { for CAD } \\
\text { NO } \\
\text { for USD }\end{array}$ & $\begin{array}{l}\text { The settlement of the cash leg takes place in } \\
\text { commercial bank money during the day, while the } \\
\text { banks' end-of-day balances are ultimately settled } \\
\text { through the BOC accounts. However, the settlement } \\
\text { risk for securities denominated in U.S. dollar is } \\
\text { concentrated on a single bank. }\end{array}$ \\
\hline \multicolumn{3}{|l|}{ Operational risk } \\
\hline $\begin{array}{l}\text { 11. Sources of operational risk arising in the } \\
\text { clearing and settlement process should be identified } \\
\text { and minimized through the development of } \\
\text { appropriate systems, controls, and procedures. } \\
\text { Systems should be reliable and secure, and have } \\
\text { adequate, scalable capacity. Contingency plans and } \\
\text { back-up facilities should be established to allow for } \\
\text { timely recovery of operations and completion of the } \\
\text { settlement process. }\end{array}$ & $\mathrm{O}$ & $\begin{array}{l}\text { The CDS has adequate measures in place to identify } \\
\text { and monitor operational risk. It also has developed a } \\
\text { contingency plan that ensures that the system can } \\
\text { resume at short notice and the information can be } \\
\text { retrieved. The procedures are tested on a regular } \\
\text { basis and market participants are involved in the } \\
\text { testing. }\end{array}$ \\
\hline Custody risk & & \\
\hline
\end{tabular}




\begin{tabular}{|c|c|c|}
\hline Responsibility & Grading & Comments \\
\hline $\begin{array}{l}\text { 12. Entities holding securities in custody should } \\
\text { employ accounting practices and safekeeping } \\
\text { procedures that fully protect customers' securities. } \\
\text { It is essential that customers' securities be protected } \\
\text { against the claims of a custodian's creditors. }\end{array}$ & $\mathrm{O}$ & $\begin{array}{l}\text { Adequate measures and arrangements are in place to } \\
\text { ensure the protection of the customers' securities. In } \\
\text { particular, participants are obliged to segregate their } \\
\text { assets from those of the customers and reconciliation } \\
\text { is done on a regular basis. }\end{array}$ \\
\hline \multicolumn{3}{|l|}{ Other issues } \\
\hline $\begin{array}{l}\text { 13. Governance arrangements for CSDs and central } \\
\text { counterparties should be designed to fulfill public } \\
\text { interest requirements and to promote the objectives } \\
\text { of owners and users. }\end{array}$ & $\mathrm{O}$ & $\begin{array}{l}\text { The CDS is owned by its major users; and its Board } \\
\text { of directors reflects the interest of shareholders, } \\
\text { users, and the public interest. The rules, procedures, } \\
\text { fees, and major decisions are all published on its } \\
\text { external website. Other publications that are } \\
\text { available on the external website include annual } \\
\text { reports and the most recent financial risk model. }\end{array}$ \\
\hline $\begin{array}{l}\text { 14. CSDs and central counterparties should have } \\
\text { objectives and publicly disclosed criteria for } \\
\text { participation that permit fair and open access. }\end{array}$ & $\mathrm{O}$ & $\begin{array}{l}\text { The access and exit criteria are clearly defined and } \\
\text { publicly disclosed. Foreign participants are subjected } \\
\text { to a specific regulatory regime based on limiting } \\
\text { systemic risk. }\end{array}$ \\
\hline $\begin{array}{l}\text { 15. While maintaining safe and secure operations, } \\
\text { securities settlement systems should be cost- } \\
\text { effective in meeting the requirements of users. }\end{array}$ & $\mathrm{O}$ & $\begin{array}{l}\text { The CDS has in place procedures aimed at reviewing } \\
\text { its pricing levels against its costs of operation. Using } \\
\text { external consultants, the CDS benchmarks its costs } \\
\text { and charges against foreign systems and assesses } \\
\text { user satisfaction with the system and the service } \\
\text { levels it provides. }\end{array}$ \\
\hline $\begin{array}{l}\text { 16. Securities settlement systems should use or } \\
\text { accommodate the relevant international } \\
\text { communication procedures and standards in order } \\
\text { to facilitate efficient settlement of cross-border } \\
\text { transactions. }\end{array}$ & $\mathrm{O}$ & $\begin{array}{l}\text { For domestic transactions, the CDS uses a } \\
\text { proprietary system with an old fashioned messages } \\
\text { interface. Internationally, it uses recognized } \\
\text { standards for cross-border transactions, such as } \\
\text { SWIFT's new messaging formats. }\end{array}$ \\
\hline $\begin{array}{l}\text { 17. CSDs and central counterparties should provide } \\
\text { market participants with sufficient information for } \\
\text { them to accurately identify the risks and costs } \\
\text { associated with using the CSD or central } \\
\text { counterparty services. }\end{array}$ & $\mathrm{O}$ & $\begin{array}{l}\text { Laws, regulations, system rules, and fees are part of } \\
\text { the contractual agreements signed by participants. In } \\
\text { particular, participants' rights, obligations and costs } \\
\text { are defined in these agreements, which are also } \\
\text { available on the CDS website. } \\
\text { The CDS has publicly disclosed the questionnaire set } \\
\text { out in the CPSS/IOSCO disclosure framework. }\end{array}$ \\
\hline $\begin{array}{l}\text { 18. Securities settlement systems should be subject } \\
\text { to regulation and oversight. The responsibilities } \\
\text { and objectives of the securities regulator and the } \\
\text { central bank with respect to SSSs should be clearly } \\
\text { defined, and their roles and major policies should } \\
\text { be publicly disclosed. They should have the ability } \\
\text { and resources to perform their responsibilities, } \\
\text { including assessing and promoting implementation } \\
\text { of these recommendations. They should cooperate } \\
\text { with each other and with other relevant authorities. }\end{array}$ & $\mathrm{O}$ & $\begin{array}{l}\text { The CDS is subject to adequate regulation and } \\
\text { supervision. The BOC oversees the CDS from a } \\
\text { systemic risk perspective, while securities regulators } \\
\text { supervise the CDS to ensure the orderly functioning } \\
\text { of the market and investor protection. Cooperation } \\
\text { between the securities regulators and BOC is } \\
\text { informal and on an ad-hoc basis. }\end{array}$ \\
\hline
\end{tabular}




\begin{tabular}{|c|c|c|}
\hline Responsibility & Grading & Comments \\
\hline $\begin{array}{l}\text { 19. CSDs that establish links to settle cross-border } \\
\text { trades should design and operate such links to } \\
\text { reduce effectively the risks associated with cross- } \\
\text { border settlement. }\end{array}$ & $\begin{array}{c}\text { NO for } \\
\text { DTC links }\end{array}$ & $\begin{array}{l}\text { The CDS has established links with securities } \\
\text { clearing and settlement systems in the United States, } \\
\text { United Kingdom, Japan, France, and Sweden as part } \\
\text { of their cross-border services. The links to the United } \\
\text { States markets are the most important ones in terms } \\
\text { of features and activities. The CDS and its } \\
\text { participants are exposed to potential credit and } \\
\text { financial risks when using the United States links. } \\
\text { The CDS permits the delivery of cross-border } \\
\text { securities, delivered through the DTC links, before } \\
\text { settlement finality is achieved in DTC svstem. }\end{array}$ \\
\hline
\end{tabular}




\section{Table 3. Recommended Action Plan to Improve Observance of CDSX of the CPSS- IOSCO Recommendations for Securities Settlement Systems}

\begin{tabular}{|c|c|}
\hline Reference Recommendation & Recommended Action \\
\hline \multicolumn{2}{|l|}{ Pre-settlement risk } \\
\hline Recommendation 4: $\mathrm{CCP}$ & $\begin{array}{l}\text { In order to fully observe this recommendation, the CDS } \\
\text { should explicitly assess the benefits and costs of acting as a } \\
\text { CCP for trade-for-trade (TFT) transactions. }\end{array}$ \\
\hline Recommendation 5: Securities lending & $\begin{array}{l}\text { The CDS might re-consider introducing a securities lending } \\
\text { facility in order to reduce settlement failure. }\end{array}$ \\
\hline \multicolumn{2}{|l|}{ Settlement risk } \\
\hline Recommendation 9: CSD risk controls & $\begin{array}{l}\text { In order to further protect the CDSX from the credit and } \\
\text { liquidity risks arising from CCP services and, as international } \\
\text { best practice, the CCP functions should be separated from the } \\
\text { settlement and custody functions, with the CCP services being } \\
\text { provided by a distinct legal entity. }\end{array}$ \\
\hline Recommendation 10: Cash settlement & $\begin{array}{l}\text { For the full observance of this recommendation, the CDS } \\
\text { needs to reduce the current concentration of settlement cash } \\
\text { for US dollar dominated securities on a single settlement } \\
\text { bank. The CDS might explore the possibility of becoming a } \\
\text { direct member of Fedwire or having access to US dollar } \\
\text { central bank money through the BOC. }\end{array}$ \\
\hline \multicolumn{2}{|l|}{ Custody risk } \\
\hline & $\begin{array}{l}\text { In order to reduce custody risk, the CDS should eliminate the } \\
\text { circulation of physical securities through its regional offices by } \\
\text { immobilizing or, preferably, dematerializing them. }\end{array}$ \\
\hline \multicolumn{2}{|l|}{ Other issues } \\
\hline Recommendation 13: Governance & $\begin{array}{l}\text { The workings of the committees set up by the CDS could be } \\
\text { made more transparent, taking into account the interests of } \\
\text { non-bank participants. }\end{array}$ \\
\hline Recommendation 16: Communication procedures & $\begin{array}{l}\text { The CDS may wish to adopt a modern messages interface that } \\
\text { is more user-friendly. }\end{array}$ \\
\hline Recommendation $18:$ Regulation and oversight & $\begin{array}{l}\text { Cooperation between the BOC and the provincial securities } \\
\text { regulators should be strengthened and formalized. The same } \\
\text { recommendation applies to the cooperation between the } \\
\text { Canadian authorities and the relevant United States authorities } \\
\text { for the cross-border activities through the links between } \\
\text { Canada and the United States. A key objective is to make the } \\
\text { regulation and oversight of clearing and settlement activities } \\
\text { more effective and transparent for both service providers and } \\
\text { market participants. }\end{array}$ \\
\hline
\end{tabular}


Reference Recommendation

Further Recommendation 19 : Cross-border links
Recommended Action

For the observance of this recommendation, the CDS should not allow the transfer of securities, delivered through the DTC links, to its participants until these securities reach settlement finality in the DTC system. Furthermore, the CDS needs to reduce the concentration on a single bank for the settlement of the cash leg in DTC.

\section{Authorities' response to the assessment}

1. The recommended action on CCP states that CDS should assess the benefits and costs of acting as a CCP for TFT transactions. Although no explicit cost-benefit analysis was undertaken, the pros and cons of offering CCP for trade-for-trade transactions were implicitly evaluated, as part of the decision to offer the TFT service without a CCP. Nonetheless, the regulators intend to raise with CDS, for its consideration, the issue of providing TFT on a CCP basis.

2. The recommended action on settlement risk states that the CCP functions should be legally separated from the custody and settlement functions, in order to protect CDSX from the liquidity and credit risks faced by the CCP. In the context of the recent corporate restructuring, the regulators raised with CDS the issue of having its CCP function in a separate legal entity. However, in light of the controls in place to mitigate the risks faced by CDS as a CCP, regulators were comfortable approving a corporate structure for CDS, which did not legally separate the CCP activities from the depository and settlement activities.

3. The recommended action on cash settlement states that CDS needs to reduce the current concentration of settlement cash for USD-denominated securities on a single settlement bank. The BOC has discussed this issue and potential solutions on several occasions with CDS, including those solutions noted in the FSAP. As a partial response to the concerns that have been raised, CDS is considering contracting a second bank to provide USD settlement services as a contingency, in the event that the bank currently being used is unable to perform this service. From the BOC's perspective, given the relatively small size of the potential financial losses, the potential efficiency loss and operational risk involved in some of the solutions, the BOC has accommodated this situation - although the intention is to continue to raise this issue with CDS, seeking possible solutions when warranted.

4. The recommended action on regulation and oversight states that cooperation between the BOC and the provincial securities regulators, as well as the cooperation between the Canadian and US authorities for cross-border links, should be strengthened and formalized. Currently, the BOC and the provincial regulators (the OSC and AMF) coordinate on an adhoc basis, as needed, depending on the issues at hand. These interactions occur at both a working level and more senior levels. There have been working-level links among the staffs of the BOC, the OSC and the AMF that have been growing, which has been beneficial. 
Furthermore, our discussions in the context of the FSAP mission have led us to the view that a more regular, formal meeting (for example, annually or semi-annually) of the three regulators would be worthwhile, to review CDSX issues from our various perspectives. If these discussions proved to be useful, we could build on this initiative with more frequent, more in-depth interactions, as needed.

5. As regards foreign oversight agencies, particularly U.S. authorities, BOC staff has been preparing a review of the oversight of cross-border clearing and settlement links more generally. This work, while still in draft form, among other things recommends regular consultation with relevant foreign regulators; for example, an annual visit with foreign regulators of most importance to the operation of CDSX. In sum, our view is to move in the direction recommended in the FSAP.

6. The recommended action on cross-border links states that CDS should not allow the transfer of securities, delivered through the DTC links, until these securities reach settlement finality in the DTC system. In DTC, credit entries to a receiver's securities account are not final until the receiver has paid for them at the end-of-day. If the receiver does not meet its end-of-day settlement obligations to DTC, then DTC can take back the securities credited provisionally to the receiver earlier that day. However, finality of settlement can occur during the business day if the receiving party instructs DTC to effect a delivery, pledge, or withdrawal of securities. Thus, the question of whether CDS allows the transfer of securities, delivered through the DTC links, before those securities reach settlement finality in DTC, depends on whether instruction by the receiver to deliver the provisionally credited securities to another participant is sufficient for its own received delivery to become final. If the answer is yes, then finality is achieved by a retransfer of the received securities (including a northbound transfer through the CDS link with DTC), and thus CDS would not be permitting a transfer of securities through its DTC link, prior to those securities reaching settlement finality in DTC. However, to answer this question definitively would require verification of how DTC rules and U.S. law work on this detail. From an oversight perspective it is not necessary to answer this question definitively, because even if the answer is no, CDS is protected through the general risk controls it has in place. In the event that the answer is no, then DTC could potentially require the replacement of securities imported into CDS, if, for example, the CDS-sponsored participant in DTC failed to meet its end-of-day payment obligations in DTC. However, in such a case, the costs associated with replacing the securities in DTC would be borne by the defaulting participant sponsored into DTC by CDS, and by surviving CDS-sponsored participants, in accordance with established CDS rules. To summarize, it may or may not be the case that CDS permits the transfer of securities via the DTC links prior to settlement finality in DTC, depending on the answer to the specific question formulated above, which deals with particular DTC rules and US legal protocol. However, even if CDS does permit such transfers, any resulting risk to CDS is sufficiently mitigated. 